\title{
Statistical Evaluation of Pacific Northwest \\ Residential Energy \\ Consumption Survey \\ Weather Data
}

\section{J. J. Tawil}

February 1986

Prepared for

the Bonneville Power Administration

under a Related Services Agreement with

the U.S. Department of Energy

Contract DE-AC06-76RLO 1830

Pacific Northwest Laboratory

Operated for the U.S. Department of Energy

by Battelle Memorial Institute 


\title{
DISCLAIMER
}

This report was prepared as an account of work sponsored by an agency of the United States Government. Neither the United States Government nor any agency thereof, nor any of their employees, makes any warranty, express or implied, or assumes any legal liability or responsibility for the accuracy, completeness, or usefulness of any information, apparatus, product, or process disclosed, or represents that its use would not infringe privately owned rights. Reference herein to any specific commercial product, process, or service by trade name, trademark, manufacturer, or otherwise, does not necessarily constitute or imply its endorsement, recommendation, or favoring by the United States Government or any agency thereof. The views and opinions of authors expressed herein do not necessarily state or reflect those of the United States Government or any agency thereof.

\author{
PACIFIC NORTHWEST LABORATORY \\ operated by \\ BATTELLE \\ for the \\ UNITED STATES DEPARTMENT OF ENERGY \\ under Contract DE-AC06-76RLO 1830
}

\begin{tabular}{|c|c|}
\hline \multicolumn{2}{|c|}{ Printed in the United States of America } \\
\hline \multirow{2}{*}{\multicolumn{2}{|c|}{$\begin{array}{l}\text { Available from } \\
\text { nal Technical Information Service }\end{array}$}} \\
\hline & \\
\hline \multirow{3}{*}{\multicolumn{2}{|c|}{$\begin{array}{c}\text { United States Department of Commerce } \\
5285 \text { Port Royal Road } \\
\text { Springfield, Virginia } 22161\end{array}$}} \\
\hline & \\
\hline & \\
\hline \multirow{2}{*}{\multicolumn{2}{|c|}{$\begin{array}{l}\text { NTIS Price Codes } \\
\text { Microfiche } \mathrm{A01}\end{array}$}} \\
\hline & \\
\hline \multicolumn{2}{|c|}{ Printed Copy } \\
\hline & Price \\
\hline Pages & Codes \\
\hline $001-025$ & $\mathrm{~A} 02$ \\
\hline $026-050$ & $\mathrm{~A} 03$ \\
\hline 051-075 & A04 \\
\hline $076-100$ & A05 \\
\hline $101-125$ & A06 \\
\hline $126-150$ & $\mathrm{~A} 07$ \\
\hline $151-175$ & $A 00$ \\
\hline $176-200$ & A0s \\
\hline $201-225$ & A010 \\
\hline $226-250$ & A011 \\
\hline $251-275$ & A012 \\
\hline $276-300$ & A013 \\
\hline
\end{tabular}




\section{4}

PNL -5776

UC -95

\section{STATISTICAL EVALUATION OF \\ PACIFIC NORTHWEST RESIDENTIAL \\ ENERGY CONSUMPTION SURVEY \\ WEATHER DATA}

J. J. Tawit

February 1986

Prepared for

The Bonneville Power Administration

under a Related Services Agreement with

the U.S. Department of Energy

Contract DE-AC06-76RLO 1830

Pacific Northwest Laboratory

Richland, Washington 99352 


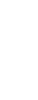




\section{SUMMARY}

This report contains the resuits of a task in the Customer System $5 f f i-$ ciency Improvement (CSEI) Assessment Project. The project is being conducted by the Pacific Northwest Laboratory (PNL) for the Office of Conservation, Bonneville Power Administration (BPA). The principal objective of the CSEI project is to assess the potential for conservation in the power systems of BPA's customers. The CSEI project complements ongoing BPA assessment work on the conservation potential in the residential, commercial, agricultural and industrial sectors and in BPA's own electric power transmission and generation system.

The current report addresses an issue relating to energy consumption and conservation in the residential sector. BPA has obtained two meteorological data bases for use with its 1983 Pacific Northwest Residential Energy Survey (PNWRES). One data base consists of temperature data from weather stations; these have been aggregated to form a second data base that covers the Nationa? Oceanographic and Atmospheric Administration (NOAA) climatic divisions. As compared to the corresponding climatic division data, the weather station data can generally be expected to more closely approximate the microclimate around a dwelling unit. However, acquiring and processing the weather station data represents a significant additional cost to BPA.

At BPA's request, Pacific Northwest Laboratory has produced a household energy use model for both electricity and natural gas. The primary objective of this study was to use this mode 1 to determine whether the statistically estimated parameters of the model significantly differ when the two different meteorological data bases are used.

Three major tasks were performed to accomplish this objective. First, the household energy use model was produced. This model consists of five components: 1) a space heating model, 2) a space cooling mode1, 3) an appliance and lighting mode1, 4) a water heating model, and 5) a consumer response model. The literature was reviewed to identify suitable relationships for these components. 
The second major task was to edit the 1983 PNWRES data. This involved substantial editing of existing variables, defining and creating new variables, and merging the billing and meteorological data with the basic household survey data.

Alternative specifications of the energy use model were evaluated through regression analysis. The final model specification was tested statistically to determine whether results using the climatic division degree-day data were significantly different from the results using the weather station degree-day data. Tests were conducted on both the ful1 edited PNWRES sample and on a restricted sample consisting only of households living in a zip code area containing a weather station.

The test results offer little evidence that weather station data is more precise than the more aggregate climatic division data. 


\section{CONTENTS}

SIMMMARY



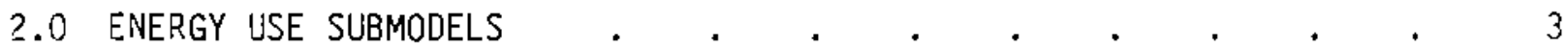

2.1 SPACE HEATING MODEL.$\quad \cdot \quad \cdot \quad \cdot \quad \cdot \quad \cdot \quad \cdot \quad \cdot \quad 4$

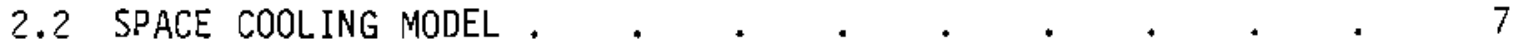

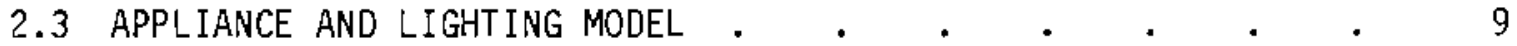

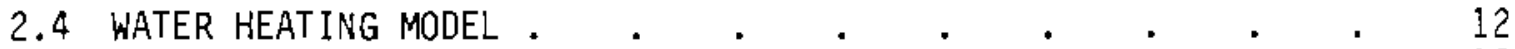

2.5 CONSUMER RESPONSE MODEL . . . . . . . . . . . . . . 12

3.0 DEFINITION AND DESCRIPTION OF VARIABLES . . . . . . . . . 14

3.1 SPACE HEATING MODEL • • . . . . . . . . . . .

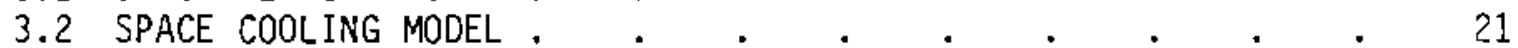

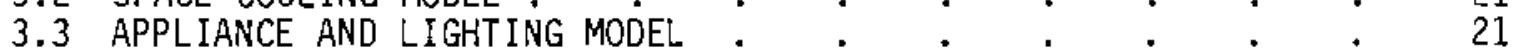

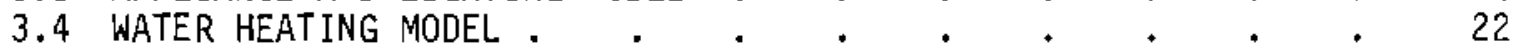

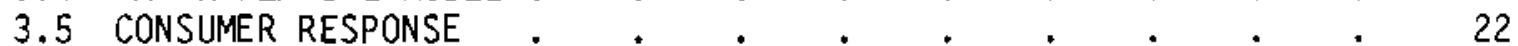

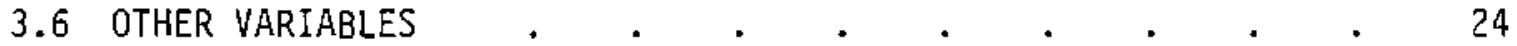

4.0 CREATING THE PNWRES SUBSAMPLE . . . . . . . . . . . . . . 25

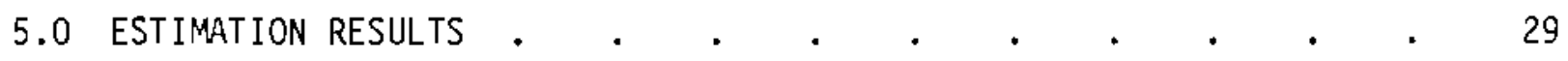

5.1 REGRESSION RESULTS . . . . . . . . . . . . . 30

5.2 TEST OF EQUTVALENCE OF WEATHER DATA $\quad \cdot \quad \cdot \quad \cdot \quad \cdot \quad \cdot \quad \cdot \quad \cdot \quad \cdot \quad \cdot \quad$

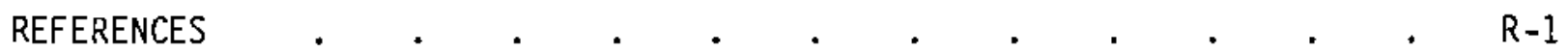

APPENDIX A $. \quad . \quad . \quad . \quad . \quad . \quad . \quad . \quad . \quad . \quad . \quad . \quad A-1$

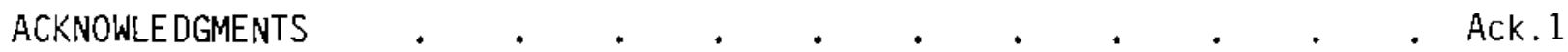


TABLES

1 Additional Exclusions from Data Set.$\quad$. . . . . . 27

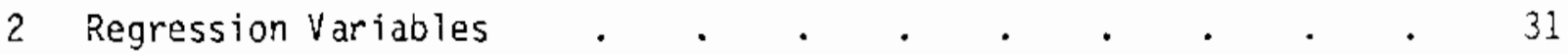

3 Electricity Consumption: Meteorological Stations, Full 5ample . 33

4 Natural Gas Consumption: Meteorological Stations, Full Sampie . 34

5 Electricity Consumption: Climate Zones, Full Sample . . . 35

6 Natural Gas Consumption: Climate Zones, Full Sample . . . 36

7 Electricity Consumption: Meteorological Stations, Restricted Sample . . . . . . . . . . . . 38

8 Natural Gas Consumption: Meteorological Stations, Restricted Sample . . . . . . . . . . . 39

9 Electricity Consumption: Climate Zones, Restricted Sample . . 40

10 Natura? Gas Consumption: Climate Zones, Restricted Sample . . 42

11 Pooled Regression: Electricity, Full Sample . . . . . . . 43

12 Pooled Regression: Natural Gas, Fult Sample . . . . . . 44

13 Pooled Regression: Electricity, Restricted Sampie . • • 45

14 Pooled Regression: Natural Gas, Restricted Samp?e . . . . 46 


\subsection{INTRODUCTION}

The 1983 Pacific Northwest Residential Energy Consumption Survey (PNWRES) data base and complementary billing and meteorological data bases have been recently released by the Bonneville Power Administration (BPA). These are currently being used to develop relationships relating to energy use in residential housing. To evaluate the importance of ambient temperature on residential energy use, BPA has obtained two meteorological data sets. One set consists of heating and cooling degree days taken directly from meterological stations located in the Pacific Northwest. The second set consists of the same weather station data, grouped and averaged to produce heating and cooling degree days for each of the National Oceanographic and Atmospheric Administration (NOAA) climatic divisions. NOAA collects and compiles these data annualiy for its climatic divisions. There are up to $10 \mathrm{climatic}$ divisions in each state, with 36 in the four states of the Pacific Northwest.

An important question for BPA concerns the extent to which the weather station data provide PNWRES users with a valuable research tool that extends beyond the usefulness of the NOAA data. The potential advantage of using the weather station data is that it more closely approximates the microclimate surrounding each respondent's dwelling, than do the more aggregate NOAA data. However, to provide the weather station data to PNWRES users, BPA must first acquire the $r$ aw weather station data, adjust it for missing values, assign each respondent to a weather station, and provide the finalized data to users. This represents a significant effort on the part of BPA.

By comparing the performance of the two data sets in explaining residential energy use, Pacific Northwest Laboratory (PNL) has evaluated the potential benefit to PNWRES users of receiving the weather station data in addition to the NOAA Climatic division data. The performance criteria were conventional statistical tests. The steps that were taken in this research effort are described below.

First, a residential energy use model was specified. The purpose of the energy use model was to account for total household energy use by the individual energy-using components. The model was used as a vehicle for comparing the two meteorological data sets. The energy use model is specified in Chapter 
2 and consists of several submodels, including a space heating submodel, a space cooling submodel, an appliance and Tighting submodel, a water heating submode1, and a consumer response submodel.

The variables used in the submodels are defined and qualified in chapter 3. The discussion in this chapter includes reporting how certain survey responses were handled, how new variables were defined, and the assumptions that were made.

In the next step, the PNWRES data were edited to provide an appropriate sample to be analyzed. For example, all respondents not using electricity or natural gas as the primary fuel for space heating were excluded. The editing procedures are described in Chapter 4.

In Chapter 5 regression equations for explaining residential energy use are specified, and the results of this statistical analysis are reported. This chapter also contains an assessment of the extent to which the weather station data set provides a useful research tool in addition to the NOAA climatic division data set.

Finally, the methodology used to produce the meteorological station data is discussed in Appendix $A$. 


\subsection{ENERGY USE SUBMODELS}

In this section we discuss the five submodels that comprise the energy use model to be estimated in Chapter 4 . The model that will be estimated is

$$
C E=a_{0}+a_{1} S H+a_{2} S C+a_{3} A P+a_{4} H H+a_{5} C R
$$

where $C E=$ household consumption of electricity (natural gas)

$\mathrm{SH}=$ design space heating requirements of the housing unit

$S C=$ design space cooling requirements of the housing unit

$A P=$ electricity (natural gas) consumption of appliances

$W H=$ electricity (natural gas) consumption for water heating

$C R=$ consumer response submode $T$.

The constants $a_{0}, \ldots, a_{5}$ are parameters to be estimated. Values for $\mathrm{SH}, \mathrm{SC}$ and $\mathrm{WH}$ are computed independently in the space heating, space cooling and water heating submodeis, respectively. SH and SC depend on the physical characteristics of the dwelling and on the heating and cooling equipment installed. WH depends on the number occupying the dwelling and on the fuel used to heat water. In the appliance and lighting submodel, the term AP is expanded to identify individual appliances. The variables in these first four submodels depend on the physical characteristics of the dwelling and the types of energy-using equipment. In the fifth submodel, the consumer response submode1, the way consumers use their electrical and natural gas equipment is considered. The amount of energy consumed is hypothesized to depend on consumers' response to the price of energy and to their household income level.

All of the variables except energy price and income are measured in average Btu/hr; price and income are measured in dollars. The model is estimated for electricity and natural gas, for meteorological station data and for climate zone data, and for a subset of the sample in which only households with a weather station within their zip code area are included. The space heating, space cooling, appliance, water heating, and consumer response models are described in the remainder of this section. 


\subsection{SPACE HEATING MODEL}

The space heating model is based largely on the heating and cooling load mode? in Dubin \& McF adden (1983); this model will be referred to as the D\&M model in this report. The D\&M model is a thermal model designed to use the survey data in the National Interim Energy Consumption Survey (NIECS) and the 1979 PNWRES. We have adapted it here for use with the 1983 PNWRES. The model requires as input certain physical characteristics of the housing unit and the type of heating and cooling equipment used. From these, the model provides estimates of the annual design energy requirements of the housing unit. A major feature of the model is that it is specified so as not to depend on the base used for computing heating and cooling degree days.

The variables used by the D\&M heating model are defined in the following section, and the model itself is specified. For information regarding the derivation of the model and other details, the reader is referred to the D\&M report.

\subsubsection{Variables Used by the Model}

The variables used in the space heating model are described below. Several of the variables are not contained in the 1983 PNWRES and had to be developed indirectly. The derivation of ali the variables used in the model is addressed in Chapter 3.

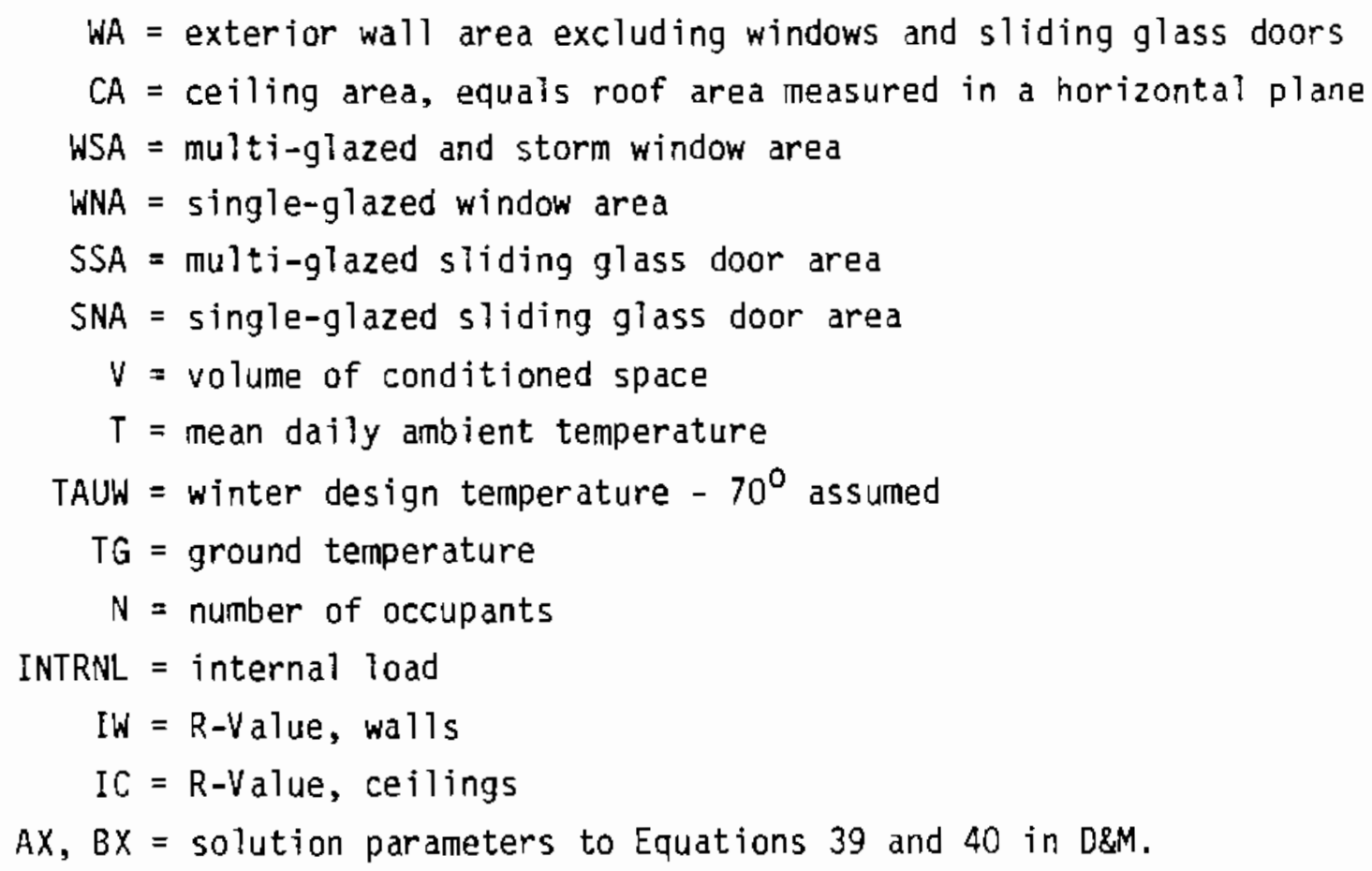


The D\&M heat load model is specified as a quadratic equation in the variable $\Delta t$, the difference betiveen the building design temperature and the ambient temperature:

$$
\text { QSEAS }=w O+W 1 \Delta t+W 2 \Delta t^{2}
$$

where QSEAS is the annual average energy consumption level for space heating under benchmark assumptions about internal load, thermostat setting and appliance use. The coefficients $W 0, W 1$ and $W 2$ are defined by the following relationships:

Let

$$
\begin{aligned}
W 0= & C A\left(\frac{75-(36+0.3 T)}{10.05}\right)(\text { TAUW }- \text { TG })-\text { INTRNL } \\
W 1= & W A\left(\frac{0.9394+0.0138 I W}{2.85+I W}\right)+C A\left(\frac{1}{3.834+0.943 I C}\right)+\frac{W S A}{2.78}+\frac{W N A}{0.98}+\frac{S S A}{1.32} \\
& +\frac{\text { SNA }}{0.88}+0.01035 \theta \mathrm{V}
\end{aligned}
$$

and $\quad W 2=0.00015 \theta \mathrm{V}$

where $\theta=1.14-\frac{0.28(W S A+S S A)}{W S A+W N A+S S A+S N A}$

and the other variabies are as defined above. Now, define the function $\Gamma(0)$ as follows:

$$
\Gamma(\delta) \div \frac{\pi^{2}}{12}+\frac{\alpha^{2}}{2}+\sum_{K=1}^{5} C_{K}{ }^{k}{ }^{K}\left(\delta^{K}-1\right)
$$

$$
\begin{aligned}
& \text { where } \quad \alpha=\max (\lambda, 0) \\
& \beta=e^{-\alpha} \\
& \delta=e^{\lambda} \\
& c_{K}=a_{K} / K \quad \text { with } a_{1}=0.99949556 \\
& a_{2}=0.49190896 \\
& a_{3}=0.28947478
\end{aligned}
$$




$$
\begin{aligned}
& a_{4}=0.13606275 \\
& a_{5}=0.03215845
\end{aligned}
$$

Also, define the balance temperature, TBALW, as

$$
T B A L W=T A U W+\frac{W 1}{2 W 2}\left(1-\left(1-4 * W 2 * W 1^{-2} \min (W 0,0)\right)^{0.5}\right)
$$

The balance temperature is the temperature above which no heating is required. If $W 0 \geq 0$, then the annual average delivered heat per hour, QSEAS, is given by

$$
\text { QSEAS }=\frac{W 0}{1+e^{-A X-B X^{\star} T A U W}}+\frac{W 1 * \ln \left(1+e^{A X+B X \star T A U W}\right)}{B X}+\frac{2 W 2}{B X^{2}} \Gamma(A X+B X \star T A U W)
$$

If $w 0<0$, then QSEAS is given by

$$
\text { QSEAS }=\frac{W 1^{\prime}}{B X} \ln \left(1+e^{A X+B X \star T B A L W}\right)+\frac{2 W 2^{\prime}}{B X^{2}} \Gamma(A X+B X \star T B A L W)
$$

where $\quad W 1^{\prime}=W 1+2^{*} W 2(T A U W-T B A L W)$

and $W 2^{\prime}=W 2$

The delivered energy requirements for natural gas furnaces and heat pumps need to be adjusted to reflect the thermal efficiency of these units. The coefficient of performance for a natural gas furnace, COPNG, is assumed to be

$$
\text { COPNG }=0.46+0.0146 \star H D 65
$$

where HD65 is the number of annual heating degree days to the base $65^{\circ} \mathrm{F}$. (This is Equation 59 in 0\&M.) The coefficient of performance for a heat pump, COPHP, is assumed to be

$$
\mathrm{COPHP}=\mathrm{HDTB} /(\mathrm{HD} 40+(\mathrm{HDTB}-\mathrm{HD} 40) / 3.25)
$$

where HDTB and HD40 are the number of annual heating degree days using, respectively, the balance temperature and $40^{\circ} \mathrm{F}$ as the base. The relationship for COPHP is from data provided by Kathleen Hudson of Cambridge Systematics in Berkeley, CA. 
Energy input in MBtu over the annual period is given by

\section{$8.76 *$ QSEAS $/$ COP $\times x$}

where COPxx is the coefficient of performance for the relevant systern.

Measured in average $B t u / h r$, the above relation is

$$
\mathrm{SH}=\mathrm{QSEAS} / \mathrm{COP} \times \mathrm{X}
$$

\subsection{SPACE COOLING MODEL}

The space cooling model is also from Dubin \& McFadden (1983) and is essentially the same as the space heating model described above. For information regarding the derivation of the cooling load model and other details, the reader is referred to the D\&M report.

\subsubsection{Variables Used in the Cooling Load Model}

The following additional variables are used in the space cooling model:

TR = mean daily temperature range

TAUS = sumner design temperature $-75^{\circ}$ assumed

Let

$$
\begin{aligned}
\text { UF } & =(\text { TAUS }-(36 .+0.3 * T)) / 10.05 \\
\text { UW } & =\left(0.9394+0.0138^{\star} \text { IW }\right) /(2.85+\text { IW }) \\
\text { UCW } & =1.0 /(3.834+0.943 * I C) \\
\text { UCS1 } & =\left(0.3769+0.00636^{\star} \text { IC }\right) /\left(2.097+0.608^{\star} \text { IC }\right) \\
\text { and UCS2 } & =\left(0.17389+0.00293^{\star} \text { IC }\right) /(2.097+0.608 \star I C)
\end{aligned}
$$

Then

$$
\begin{aligned}
& \text { SO }=\left(W A^{\star} U W *(362.1-0.9638 * T R)+\frac{C A^{*} U C S 1^{*}\left(355.6-1.032^{*} T R\right)}{24 .}+\right. \\
& (W S A+W N A+S N A)^{\star}(0.8 * \text { TAUS }-30.0)+\text { SSA* }(0.6 * \text { TAUS }-18.0)+ \\
& 1000 * \text { INTRNL ) } 1.25
\end{aligned}
$$




$$
\begin{aligned}
S 1 & =\left(\frac{W A \cup W \star 22.67+C A * U C S 1 * 22.66+C A * U S C 2 * 24.0}{24.0}+(W S A+W N A+S N A) * 0.8\right. \\
& +S S A * 0.6+0.00742 \star V) 1.25 \\
S 2 & =0.00015 \star V \star 1.25
\end{aligned}
$$

and the other variables are as defined above. Also, define the summer balance temperature, TBALS, as

$$
\text { TBALS }=\text { TAUS }+\frac{S 1}{2 S 2}\left(1-\left(1-4 \star S 2 \star S 1^{-2} \min (S 0,0)\right)^{0.5}\right)
$$

The summer balance temperature is the temperature below which no cooling is required. Finally, define

$$
\begin{aligned}
& S 0^{\prime}=S O+S 1^{\star}(\text { TBALS }- \text { TAUS })+S 2^{\star}(\text { TBALS }- \text { TAUS })^{2}=0 \\
& S 1^{\prime}=S 1+2.0^{\star} S 2^{\star}(\text { TBALS }- \text { TAUS }) \\
& S 2^{\prime}=S 2
\end{aligned}
$$

Then, if $S O \geq 0$, the annual average delivered energy per hour, $Q A C$, is given by

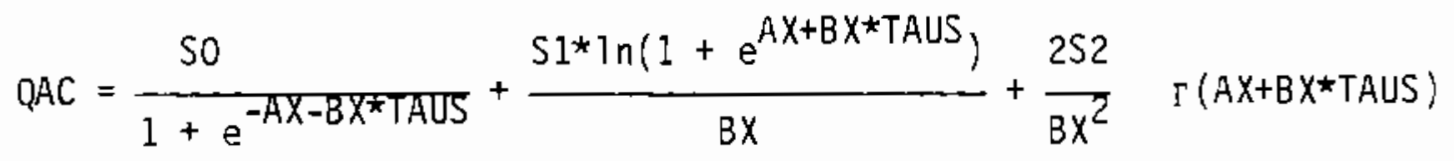

If $S O<0$, then $Q A C$ is given by

$$
\text { QSEAS }=\frac{S 1^{\prime}}{B X} \ln \left(1+e^{A X+B X * T B A L S}\right)+\frac{2 S 2^{\prime}}{B X^{2}} \Gamma(A X+B X * T B A L S)
$$

The delivered energy requirements need to be adjusted to reflect the thermal efficiency of air conditioning units. For an air conditioner, the coefficient of performance, COPAC, is assumed to be

$$
\text { COPAC }=3.44+\frac{0.744}{H 065}+\frac{1.23}{\operatorname{CD} 65}-0.036 * H D 65-0.038 * \operatorname{CD} 65
$$

where $H D 65$ and CD65 are the number of respective annual heating and cooling degree days to the base $65^{\circ} \mathrm{F}$. (This is Equation 63 in D\&M.)

Energy input in MBtu for space cooling over the annual period is given by $8.76 \star Q A C / C O P A C$ 
Measured in average $\mathrm{Btu} / \mathrm{hr}$, the above relation is

$$
S C=Q A C / C O P A C
$$

\subsection{APPLIANCE AND LIGHTING MODEL}

The appliance and lighting model is based on an empirical analysis conducted on the 1980 Residential Energy Consumption Survey (RECS) by Latta (1983). The RECS data are from a national survey. Latta's anaiysis consists of regression equations estimated for single-family detached housing units, mobile homes, single-family attached units, and units in smali and large apartment buildings. Gas and electric consumption were separately considered. In the Latta model, energy consumption is computed as the sum of four components: 1) space heating, 2) space cooling, 3) hot water and 4) lighting and appliances. This model differs from ours in two respects: 1) our model is based on design energy use for both heating and cooling, while the corresponding variables in Latta's model are for actual energy use; and 2) Latta's model does not include energy price and household income, our consumer response variabies.

We use Latta's estimated appliance and lighting model, described below, to compute the interna] load--variable INTRNL--in the space heating and cooling submodels described in Section 1.1. However, to estimate the effects of appliances on energy consumption, we include individual major appliances in our estimated model. The energy used by lighting and minor appliances is assumed to be estimated primarily by the intercept term. Because Latta's appliance equation is used to compute our internal load variable, we devote the remainder of this section to a description of Latta's appliance and lighting submodel.

Energy consumption by appliances was considered in two components: electrical energy consumption, EAPLOAD; and natural gas consumption, GAPLOAD. EAPLOAD and GAPLOAD are estimated as follows:

Let ADULTS = the number of occupants 13 years old and above

VINTAG = the age of the housing unit

PSTRM = percent of window and sliding glass door area that is insulated or has storm windows

HEATED = total square feet of conditioned area 


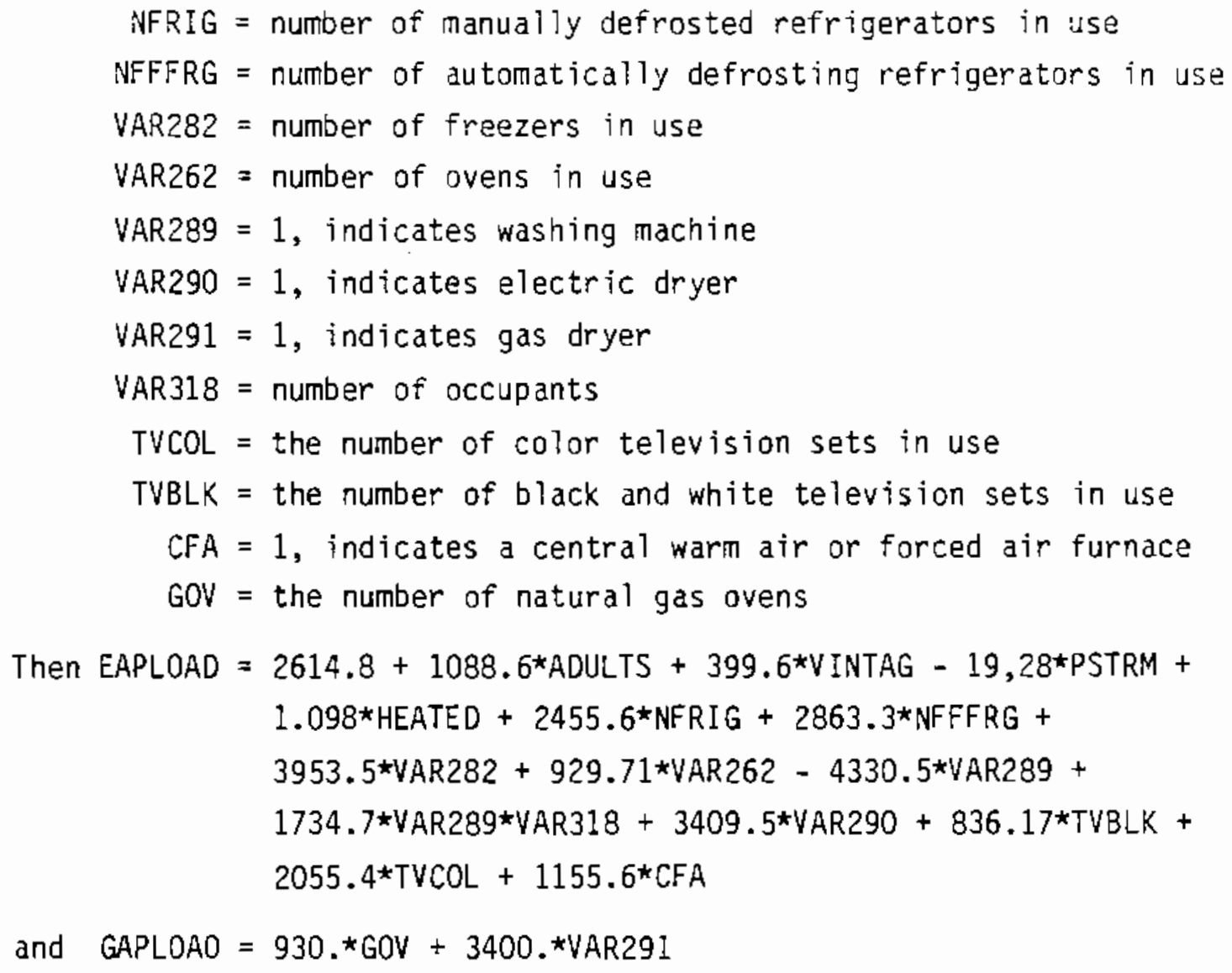

The above relationships are taken from Latta (1983; pp. 31-2). Latta also has terms for swimming pools, heated pools and wringer-type washing machines. Our sample excludes the few individuals who heat their swimming poois with electricity or natural gas (see Chapter 4). With regard to wringer-type washing machines, the 1983 PNWRES does not identify these separately; however, they are presumed to be sufficiently rare so as not to affect the results.

The appliance and lighting equations give energy consumption in MBtu for a one-year period. To convert MBtu to hourly load in Btu--the units used in the space heating and cooling modeis--we multipiy EAPLOAD and GAPLOAO by $1.0 /(8.760)$.

Latta provides adjustment factors for dwelling units other than singlefamily detached (Latta 1983; p. 83). The coefficients for mobile homes, singlefamily attached, units in small apartment buildings, and units in large apartment buildings are $+0.1491,-0.1639,-0.1545$ and -0.1734 , respectively, for electric appliances and lighting. Unfortunately, the PNWRES building type 
classification does not correspond exactly to that of the RECS survey; the former uses multi-family attached/detached, while the latter uses units in small/large apartment buildings. However, Latta's coefficient for the singlefamily attached is close to and nearly midway between the coefficients for apartments. The coefficient for single-family attached was therefore used to adjust all dwelling types except mobile homes. Thus, the electric lighting and appliance energy consumption equation in its general form is:

$$
\begin{aligned}
& \text { EAPLOAD' }=(1.0+0.1491 * M O B-0.1639 *(S F A 1+S F A 2+M F D+M F A 1+M F A 2+M F 5)) * \\
& \operatorname{EAPLOAD*}(1.0 / 8.76) \\
&(B t u / h r)
\end{aligned}
$$

where $\begin{aligned} \text { MOB } & =1, \text { indicates mobile home } \\ \text { SFA1 } & =1, \text { indicates single-family, attached one side } \\ \text { SFA2 } & =1, \text { indicates single-family, attached two sides } \\ M F A 1 & =1, \text { indicates multi-family, attached one side } \\ M F A 2 & =1, \text { indicates multi-family, attached two sides } \\ M F D & =1, \text { indicates multi-family detached } \\ M F 5 & =1, \text { indicates multi-family with } 5 \text { or more units }\end{aligned}$

The method used by Latta to adjust the estimates of natural gas consumption for dwelling type does not permit the adjustment to be made for gas appliances oniy. Therefore, we arbitrarily used the adjustment factor for electric appliances and lighting to make the adjustment for natural gas. Thus,

$$
\begin{aligned}
& \text { GAPLOAD' }=(1.0+0.1491 * M O B-0.1639 *(S F A 1+S F A 2+M F D+M F A 1+M F A 2+M F 5)) \star \\
& \text { GAPLOAD* }(1.0 / 8.76) \\
&(B t u / h r)
\end{aligned}
$$

As already noted, the estimated coefficients from Latta's appliance and lighting model are used only to compute internal loads in the space heating and cooling models. To estimate electricity and natural gas consumed by appliances and lighting from the 1983 PNwRES data, we used in our estimating equation essentially the same variables used by Latta. The coefficients for these variabies were determined from a regression. 


\subsection{WATER HEATING MODEL}

The water heating submodel is also based on Latta's analysis of the RECS data. The estimated relationship for electric water heating for single-family detached units is

$$
\text { EWH }=3966.7+2156.9 * \text { VAR318 + 3337.8*TEENS + 4903.6*VAR292 }
$$

where $\quad E W H=$ annual consumption of electricity, in MBtu, to heat water VAR318 = number of occupants

TEENS = number of teenagers in the household VAR292 = 1, indicates an electric dishwasher

After making adjustments for building type and converting the energy units into hourly Btu, the equation becomes

$$
E L C O N W H=\frac{(1-0.4084 * M O B-0.1639 *(S F A 1+S F A 2+M F D+M F A 1+M F A 2+M F 5))^{\star E W H}}{8.76}
$$

where $\mathrm{WH}=$ hourly Btu consumed in heating water, and the other variables are as previously defined.

\subsection{CONSUMER RESPONSE MODEL}

Energy users will adjust their consumption of energy based on their preference for comfort, their income and the price of energy. Since the energy crisis of 1974, methods of conserving household energy have become widely known. Commonly adopted conservation measures and strategies include altering thermostat settings, closing off rooms in winter, including conservation measures in new building construction, reducing temperature settings on hot water heaters, installing hot water savers on showers and appliances, and using energy-efficient appliances.

The effect on energy consumption of such conservation responses can be evaluated through multiple regression analysis. In the current model, we measure some of these responses with energy price and household income variables. The followind discussion considers which of the conservation responses are measurable by these variables. 
The nature of multiple regression analysis is to explain variations in the dependent variable through the presence of independent or explanatory variables. In the model that we have been describing, some conservation-related measures are considered explicitly, while others are not. For example, the amount of roof insulation and the number of refrigerators in use are explicitiy considered while thermostat settings and the energy efficiency of the refrigerators are not. If a conservation measure is not considered explicitly, its influence on variations in the dependent variable must be "explained" by other variables in the model or must be absorbed into the the disturbance term. The energy price and household income variables have been included in the model to "explain" the influence on energy consumption of those conservation measures not explicitly included.

From the above explanation, it should be clear which conservation measures have an explicit effect on the dependent variable and which have an effect through the energy price and household income variables. One measure--closing off rooms to conserve fuel during winter--deserves further elaboration. The O\&M space heating and cooling models assume that all of the living space included in the model is conditioned. To the extent that unheated areas have been included in the reported square footage variable (Variable 473), varjations in household energy usage from closing off rooms will be "explained" by the energy price and income variables. Whether such areas have been included is not altogether clear. Instructions to the interviewer were: "[i]n genera], [to] measure all parts of the housing unit which are used as yearround living quarters." However, the computed areas are based on interviewerconstructed "floor plans," and it seems likely that these may have been based on exterior walls. Also, interviewers were instructed to include basements if at least some portion was heated; and attics were to be excluded only if they were both unheated and unfinished (PNWRES 1983).

Other conservation measures for which variations in household energy usage are "explained" by the energy price and income variables include lowered thermostat settings in winter and reduced use of air conditioning in summer, increased appliance efficiency, reduced temperatures for heating water, reduced lighting, and hot water saving devices.

In the following section, we describe and qualify the variables that are used in the submodels described in this section. 


\subsection{DEFINITION AND DESCRIPTION OF VARIABLES}

In this section we define the variables used in each of the five energy use submodels. When appropriate, we discuss any qualifications or assumptions that have been applied. Variables that are taken from the 1983 PNWRES are indicated with the variable number following the letter $V$. For example, V250 refers to variable 250, as denoted in PNWRES (1983). Many of the variables required for estimating the energy use submodels are not in the PNWRES data and therefore had to be derived indirectly. This required defining and using additional variables. The format for presenting this information is as follows: the variables used directly in the energy use submodels are recorded at the left margin and their description is underlined. Additional variables that are needed to define these and that have not been previously defined are indented.

\subsection{SPACE HEATING MODEL}

The space heating model is used to estimate the design heating requirements of the housing unit. Consequently, "nonphysical" factors that affect space heating usage, uch as the interior thermostat setting, are excluded from the estimate. The variables used by the space heating model are described below and in Section 3.6.

WA Exterior Wall Area Excluding Windows and Sliding GIass Doors

The following variables are used to estimate WA:

WDA = total square footage of windows and sliding glass doors WDA is estimated with the following relationship:

$$
\begin{aligned}
\text { WDA }= & -34.493364+3.558968 \star S Q R T(V 473)+81.43361 * V 147 \\
V 473= & \text { square footage of housing unit used for year }- \\
& \text { round living } \\
V 147= & \text { number of sliding glass doors }
\end{aligned}
$$

The above relationship was statistically estimated by running a regression using the measurement data from 7 "typical" dwelling units documented in Dubin \& McFadden (1983; Table 17). This estimating procedure was used because the 1983 PNWRES reported no information on window area and comparable information was not readily available from other sources. 
SDAT = total sliding glass door area

$$
\text { SDAT }=53 * V 147 \quad \text { (square feet) }
$$

In seven "typical" dwellings where several measurements were taken, the average for sliding glass doors was found to be 53 sq. ft. (Dubin \& McFadden 1983; Table 17).

WAX = exterior wall area, including doors and windows

$W A=W A X-W D A-$ SDAT. $\quad$ (square feet)

SSA Sliding Glass Door Area, Insulated or Stormed

$$
\begin{aligned}
& S S A=53 * V I 48 \quad \text { (square feet) } \\
& \text { V148 }=\text { number of insulated sliding glass doors }
\end{aligned}
$$

SSN Sliding Glass Door Area, Single-Glazed

SSN = SDAT - SSA (square feet)

WSA Stormed Window Area

Let IGF = fraction of windows having insulated/thermopane glass (V153)

SWF = fraction of windows having storm windows (V154)

PLF = fraction of windows having plastic covers (V155)

The above varjables were evaluated from the survey responses.

The responses and the assigned values are:

$$
\begin{aligned}
\text { "None" } & =0.0 \\
\text { "Less than 10\%" } & =0.05 \\
\text { "10-39\%" } & =0.25 \\
" 40-59 \% " & =0.50 \\
" 60-89 \% " & =0.75 \\
\text { "90-100\%" } & =1.0 .
\end{aligned}
$$

Then WSA $=(I G F+S W F+P L F)^{\star W D A} \quad$ (square feet)

The sum of IGF, SWF and PLF was restricted not to exceed 1.0. Note also that windows with insulating measure "other" (V156) were excluded from this calculation.

WNA Nonstormed Window Area

$$
\text { WNA = WOA - WSA - SSA - SSN (square feet) }
$$

CA Ceiling Area

$$
\text { Let } \begin{aligned}
& V 469=\text { square feet of conditioned space on floor } 1 \\
& V 470=\text { square feet of conditioned space on floor } 2 \\
& V 471=\text { square feet of conditioned space on floor } 3 \\
& \text { Then } \quad C A=\operatorname{Max}(V 469, V 470, V 471) \\
&
\end{aligned}
$$


The ceiling area variable is used to compute the heat loss through the roof. Since the relevant area was not directly reported, it was assumed to consist of the largest of the areas comprising each floor, excluding the basement. Normally, this would be the first floor area, but if, for example, the second fjoor extended over an unheated garage or carport, then the second floor area could be larger than the first floor area and therefore would be taken as the ceiling area. If none of variables 469 through 472 were reported but total square feet was reported in V473, then CA was computed by dividing variable V473 by FLRS, where FLRS is based on $V \dot{408}$ and is defined as follows:

A default value of 1 was given to the number of floors used as living quarters. This default value was assigned to any respondent not reporting the number of floors or levels. In addition, a response of more than 3 floors was assigned the value 4; a split level with two levels was counted as 1 floor; a split level with 3 levels was counted as $1-1 / 2$ floors; and a split level with more than 3 levels was counted as 2 floors.

Volume of Conditioned Space

$V=8 * V 473 \quad$ (cubic feet)

Eight-foot ceilings are assumed.

Mean Ambient Daily Temperature

$A X, B X=$ the coefficients estimated for the Dubin-McF adden thermal efficiency model (Dubin \& McFadden 1983; Equations 39 \& 4D)

$T=-A X / B X \quad$ (degrees $F$ )

$A X$ and $B X$ were computed from the heating and cooling degree day data with base $65^{\circ} \mathrm{F}$. Four pairs of these values were generated for each member of the sample as follows: 1) station data, natural gas; 2) station data, electricity; 3) climatic division data, natural gas; and 4) climatic division data, electricity. The values were obtained by using a computer routine to solve a pair of nonlinear equations for these parameters.

TAUW Winter Design Temperature

Assumed to equal 70 . (degrees F)

TG Ground Temperature

$T G=T-(18 *$ ORE + 18*WAS + 19*IDA + 20*MON) (degrees F)

(Based on ASHRAE 1977)

The ground temperature affects the heat loss through basement walls and the flooring on the ground floor. The coefficients of the dummy variables ORE, WAS, IDA and MON represent the annual ranges in ground temperature at a depth of 4 inches.

V318 Number of Occupants 


\section{INTRNL Internal Load}

The internal load is made up of heat energy from lighting, appliances, building occupants, and solar gain. The internal load calculation for lighting and appliances is based on Latta (1983) and is discussed in Sections 2.3 and 3.3 .

In calculating internal load, we assume that, with the exception of energy used for heating water, all energy used by appliances and lighting iltimately becomes heat energy and contributes to the internal load. To assume that none of the energy used in heating water contributes to the internal load may cause the internal load to be understated. However, adding all of the energy used by clothes dryers to internal load will tend to overstate the internal load because much of the heat from these appliances may be vented outdoors.

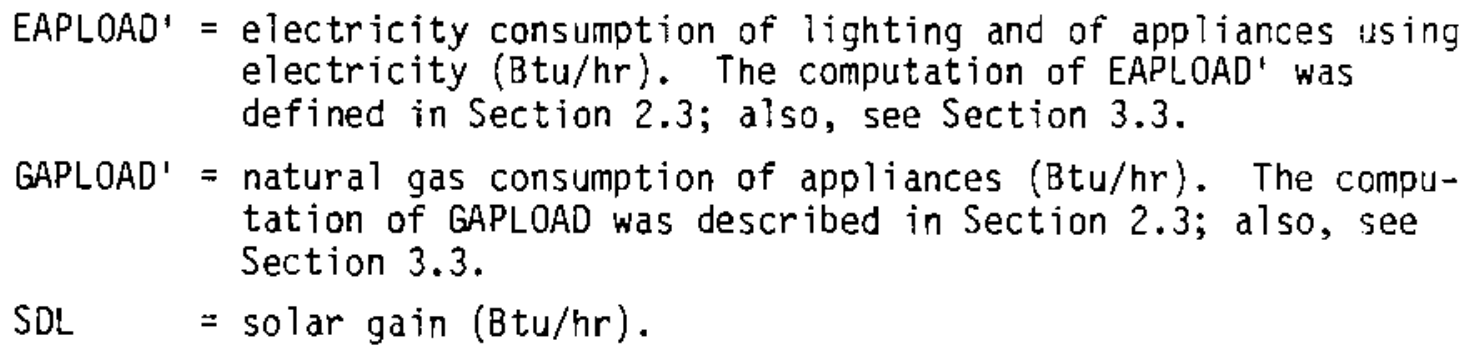
electricity $(B \mathrm{tu} / \mathrm{hr})$. The computation of EAPLOAD' was defined in Section 2.3; also, see Section 3.3.

GAPLOAD' = natural gas consumption of appliances (Btu/hr). The computation of GAPLOAD was described in Section 2.3; also, see Section 3.3.

SOL $=$ solar gain (Btu/hr).

Solar gain was estimated using the following relationship developed by KathIeen Hudson of Cambridge Systematic, Berkeley, CA.

$$
\begin{aligned}
& \text { PCTCLR = the fraction of the daytime hours in which the } \\
& \text { weather is clear. PCTCLR value is } 0.6 \text { for Montana, } \\
& 0.5 \text { for Idaho and } 0.4 \text { for Washington and Oregon. } \\
& \text { PCTCLR }=0.6^{\star M O N}+0.5^{\star} \mathrm{IDA}+0.4^{\star} \text { WAS + } 0.4^{\star} \mathrm{ORE} \\
& \text { WAS = Washington (durmy variable) (V2) } \\
& \text { Eastern and Western Washington were aggregated } \\
& \text { into a single variable. } \\
& \text { ORE = Oregon (dummy variabie) (V2) } \\
& \text { Eastern and Western Oregon were aggregated } \\
& \text { into a single variable. } \\
& I D A=\text { Idaho (dumny variable) (V2) } \\
& \text { MDN = Montana (dummy variable) (V2) } \\
& \text { SHDG = shading factor for insulated/stormed glass } \\
& \text { SHDG }=0.9 \\
& \text { SOL }=1000 . \star P C T C L R \star S H D G \star(W S A+S S A) /(24 * W D A) \quad(B t u / h r) \\
& \text { INTRNL }=(\text { EAPLOAD' }+ \text { GAPLOAD' })+225 \star V 318+\text { SOL } \quad(B t u / h r)
\end{aligned}
$$


R-Value, walls

The 1983 PNWRES does not directly inquire about the amount of insulation in the walls; however, it does contain two questions that can be used to construct an estimate. V131 asks for the percentage of the outside walls that contain insulation; $V 49$ relates to the respondent's perception of the energy efficiency of his home. Values for $I_{w}$ were constructed based on responses to these two variables as follows:

$$
\text { R-Values, Walls }
$$

Perc. of Walls

Potentia) Improvement in Energy Efficiency of Home

Insulated



The entries in the above tabie are based on judgment. A default value of R-11 was used for responses not falling in any of the above categories. Besides using frequency information on the two variables noted, information from the following table was also factored in. The information is based on surveys of new-home builders in the Pacific states for the years indicated.

\begin{tabular}{c}
$\begin{array}{c}\text { Exterior Wali Insulation, Single-Family Detached } \\
\text { Pacific States, Selected Years } \\
\text { (percent of units with R-value) }\end{array}$ \\
R-Value \\
\hline
\end{tabular}

*Based on a mix of dwelling types in the Western Region.

Source: (OTA 1979)

Ic R-Value, Ceilings

Although the 1983 PNWRES does not directly inquire about the amount of insulation in the ceilings, it does contain two questions that can be used to construct an estimate for the amount of ceiling insulation. 
$V 133$ asks for the percentage of the ceiling that contains insulation, and $V 49$ relates to the respondent's perception of the energy efficiency of his home. Values for I were constructed based on responses to these two variables as follows:

$$
\text { R-Values, Ceilings }
$$

Percent of Ceilings

$\frac{\text { Potential Improvement in Energy Efficiency of Home }}{\text { None A Little }}$

Insulated

$\begin{array}{lrrrr}\text { None } & g & 9 & 0 & 0 \\ 1-10 \% & 11 & 11 & 9 & 9 \\ 10-39 \% & 13 & 13 & 11 & 11 \\ 40-59 \% & 13 & 13 & 13 & 13 \\ 60-89 \% & 18 & 18 & 18 & 13 \\ 90-100 \% & 19 & 19 & 19 & 19 \\ \text { Don't Know } & 19 & 13 & 11 & 9\end{array}$

The entries in the above table are based on judgment. A default value of R-13 was used for responses not falling in any of the above categories. Besides using frequency information on the two variables noted, information from the following table was also factored in. The information is based on surveys of new-home buiters in the Pacific states for the years indicated.

Exterior Ceiling Insulation, Single-Family Detached Pacific States, Selected Years (percent of units with R-value)

\begin{tabular}{lrrr} 
R-Value & $1975-6$ & 1974 & $1973^{*}$ \\
\hline None & 0.7 & 4.8 & 3.0 \\
R7 & 0.3 &.-- & 0.2 \\
R9 & --- & 4.5 & 17.0 \\
R11 & 2.5 & 16.3 & 11.5 \\
R13 & 12.8 & 28.2 & 38.5 \\
R18 &.-- & 4.4 & 1.2 \\
R19 & 80.9 & 41.6 & 16.8 \\
R22 & 0.9 & 0.1 & --- \\
R30 & 0.8 & --- & -- \\
R31 & 0.3 & --- & -- \\
$>$ R31 & 0.4 & -- & --
\end{tabular}

*Based on a mix of dwelling types in the Western Region. Source: (OTA 1979) 


\subsection{SPACE COOLING MODEL}

In addition to the variables defined above and in Section 3.6, the space cooling model requires two additional variables:

TAUS Surmer Design Temperature

Assumed to equal 75 . (degrees F)

TR Mean Daily Temperature Range, Summer

$T R=30 \star 0 R E+29 \star W A S+33 \star I D A+32 \star M O N$

(degrees F)

(Weather Data 1978)

\subsection{APPLIANCE AND LIGHTING MODEL}

The following variables were used in estimating the electricity and natural gas consumption of appliances and lighting.

ADULTS = the number of residents 13 years old and above (V319 - V358)

This variable is used to adjust appliance use to the number of adults in the household.

VINTAG = the age of the dwelling unit $\left(V_{23}, V 24\right)$; values were assigned as follows:

$$
\begin{array}{r}
\text { Before 1940, VINTAG }=1.0 \\
1940-1949, \text { VINTAG }=2.0 \\
1950-1959, \text { VINTAG }=3.0 \\
1960-1964, \text { VINTAG }=4.0 \\
1965-1969, \text { VINTAG }=5.0 \\
1970-1974, \text { VINTAG }=6.0 \\
1975-11 / 30 / 81, \text { VINTAG }=7.0
\end{array}
$$

For respondents reporting a range of values (V24) instead of a specific value (V23), a response indicating a construction year between 1960 and 1969 was given a value of VINTAG $=4.5$.

NFFFRG $=$ number of automatic defrosting refrigerators

NFFRGI = 1 if refrigerator \#I is automatic defrosting; 0 otherwise (V280)

NFFRG2 = 1 if refrigerator \#2 is automatic defrosting; 0 otherwise (V281)

NFFFRG $=$ NFFRG1 + NFFRG2

NFRIG = the number of manually defrosted refrigerators.

V275 $=$ number of refrigerators in use

NFRIG $=$ V275 - NFFFRG

V282 = number of freezers in use

$v 262=$ the number of ovens in use 


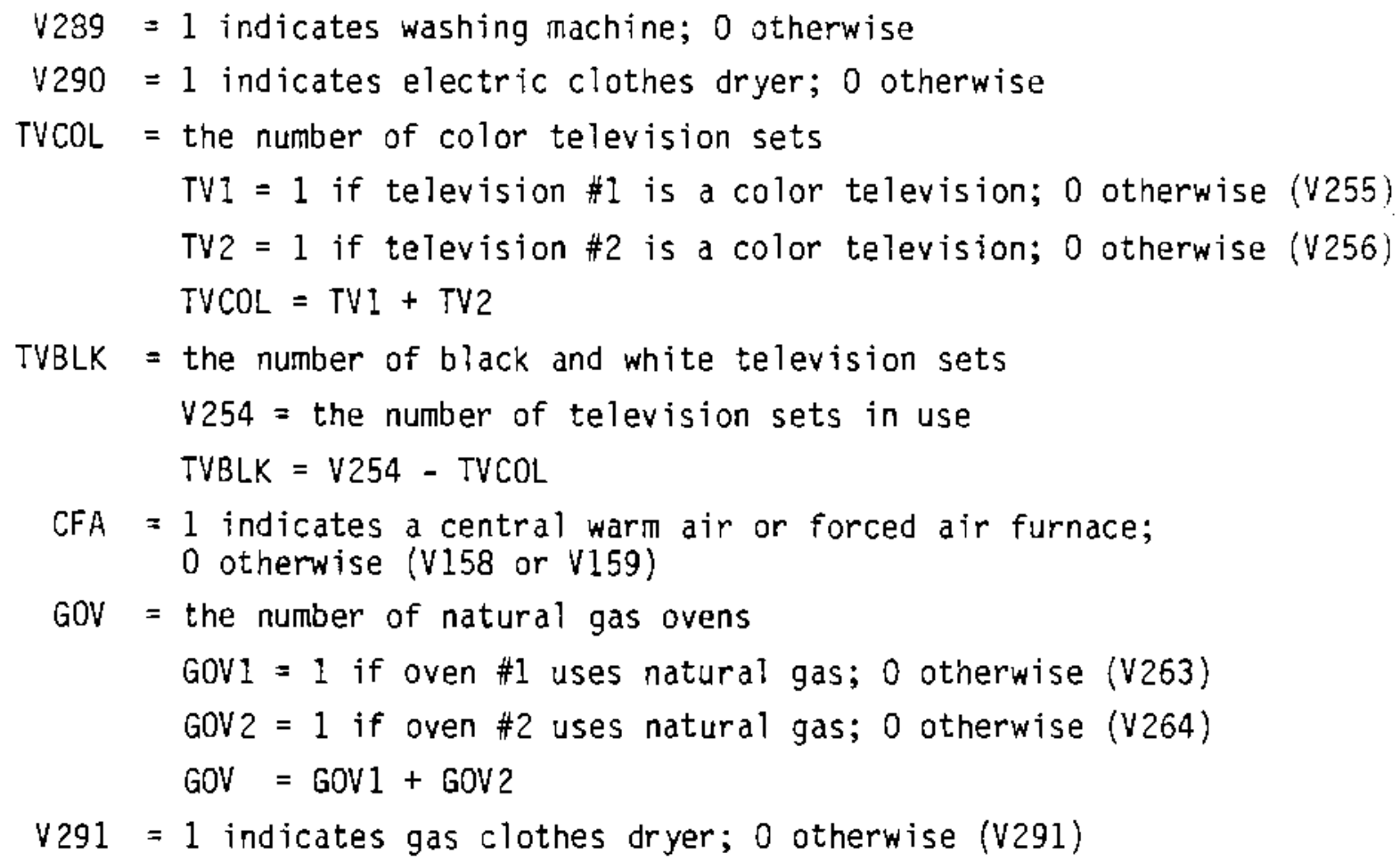

\subsection{WATER HEATING MODEL}

The following variables were used in estimating the water heating model.

\section{VAR318 Number of Residents}

TEENS Number of Teenagers in Household

This variable was evaluated from variables $v 321$ through $v 358$ as

follows:

If the exact age of the householder was given and the person was between the ages of 13 and 19 , that person was included in the TEENS count. If an exact age was not given but the person was in age category 3, that person was included in the TEENS count.

V292 Electric Dishwasher is Present

This variable equals 1 if an electric dishwasher is present, and 0 otherwise.

\subsection{CONSUMER RESPONSE MODEL}

The purpose of the consumer response submodel is to account for consumer adjustments in energy consumption which are not directly traceable to variables included explicitly in the model. We account for these adjustments with two 
variables: energy price and household income. Our hypothesis is that, other things remaining equal, higher energy prices will cause more energy users to take actions to reduce energy consumption; and, other things remaining equal, higher household incomes will result in higher energy consumption. Energy price and household income are defined as follows:

EPRICE Price of Electricity

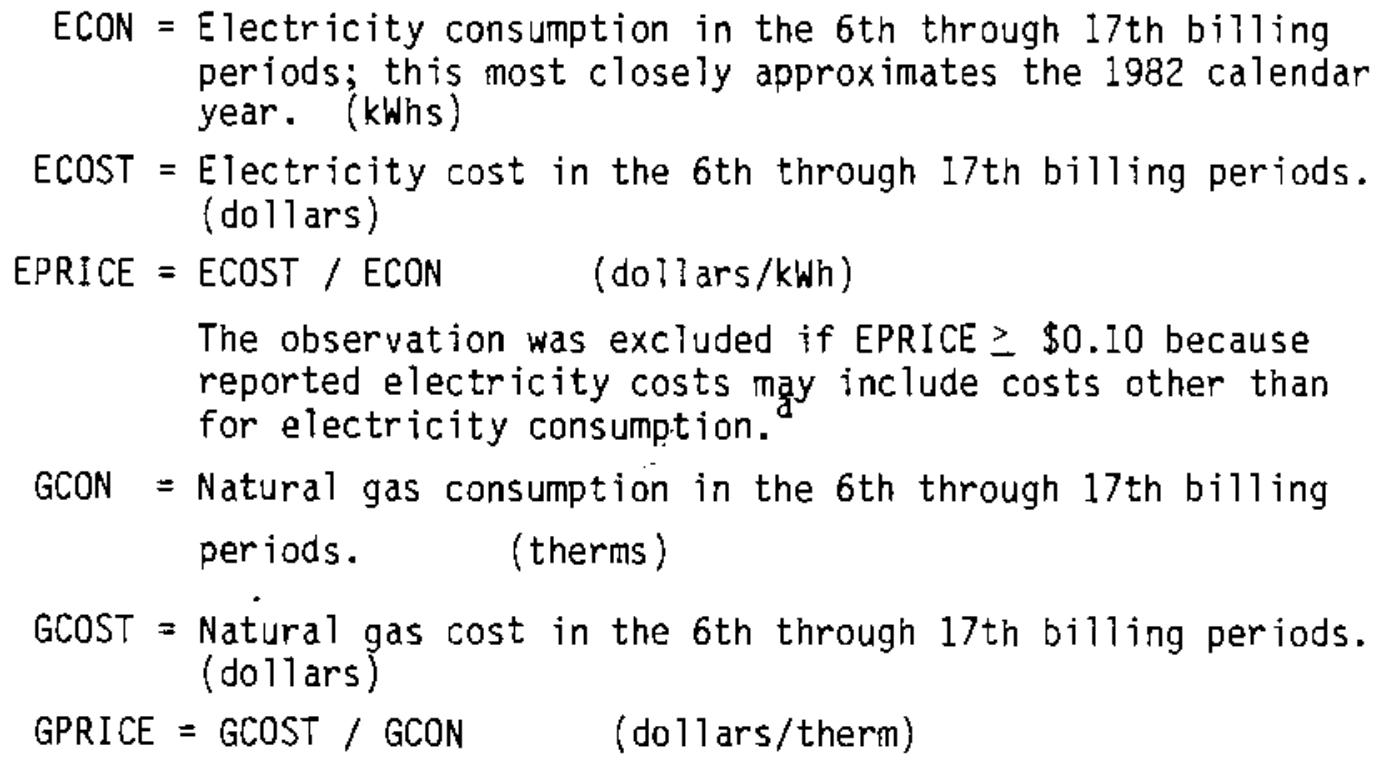

NVAR364 Household Annual Income

This variable was evaluated from variable v364 and value was assigned as follows:
under $\$ 5,000$, NVAR364 $=\$ 4,000$
$\$ 5,000-\$ 7,999$, NVAR364 $=\$ 6,500$
$\$ 8,000-\$ 9,999$, NVAR364 $=\$ 9,000$
$\$ 10,000-\$ 11,999$, NVAR364 $=\$ 11,000$
$\$ 12,000-\$ 13,999$, NVAR364 $=\$ 13,000$
$\$ 14,000-\$ 15,999$, NVAR $364=\$ 15,000$
$\$ 16,000-\$ 17,999$, NVAR364 $=\$ 17,000$
$\$ 18,000-\$ 19,999$, NVAR364 $=\$ 19,000$
$\$ 20,000-\$ 24,999$, NVAR364 $=\$ 22,500$
$\$ 25,000-\$ 29,999$, NVAR364 $=\$ 27,500$
$\$ 30,000-\$ 34,999$, NVAR364 $=\$ 32,500$
$\$ 35,000-\$ 39,999$, NVAR364 $=\$ 37,500$
$\$ 40,000-\$ 49,999$, NVAR364 $=\$ 45,000$

(a) Bill Monroe, a statistical analyst at Electronic Data Systems, provided the basis for selecting $\$ 0.10$ as the cutoff point. He took the maximum prices reported for all billing periods and found that approximately $95 \%$ of these were under $\$ 0.10$ per $\mathrm{kwh}$. 


$$
\begin{aligned}
& \$ 50,000-\$ 59,999, \text { NVAR } 364=\$ 55,000 \\
& \$ 60,000-\$ 74,999, \text { NVAR364 }=\$ 67,500 \\
& \$ 75,000 \text { or over, NVAR364 }=\$ 90,000 .
\end{aligned}
$$

\subsection{OTHER VARIABLES}

In addition to the variables defined in Sections 2.1 and 2.2 , adjustment factors F1 and F2 are defined for use in the space heating and cooling models. The adjustment factors are used in processing attached building units. If a building unit is attached, we assume that there is no heat loss through the common wal1(s). For a building with five or more units, we assume that there is no heat loss through two walls, the ceiling and the floor.

The factors FI and $F 2$ are used to reduce the wall, ceiling and floor areas accordingly. For a single- or multi-family unit that is attached on one side, the wall area is decreased by $25 \%$. For a single- or mu?ti-family unit attached on two sides, the walt area is decreased by 50\%. For a unit in a building with five or more units, the wall area is decreased by $50 \%$ and the effective area of the floor and ceiling is zero square feet. An assumption implicit in the above procedure is that the attached unit is square; i.e., the common wall is the same size as each exterior wall. 


\subsection{CREATING THE PNWRES SUBSAMPLE}

This section describes the measures that were taken to obtain an appropriate subsample from the full PNWRES data set. The objective here was to construct a data set that met the following two criteria: 1) it should contain variables that can adequately explain residential energy consumption, and 2) it should lead to a clear statistical test of the incremental value of using the weather station data over the more aggregate climate division data. To meet the second requirement, the proportion of variance explained by at least one of the weather variables must be high relative to the unexplained variance. This can be accomplished by reducing the unexplained variance to the extent practicable.

Consider the following example, which illustrates measures that were taken to reduce the unexplained variance. To account for electricity use among households that heat a swimming pool with electricity, we could use a dumny variable for swimming pool ownership. Alternatively, we could exclude these households entirely from the sample. The latter course results in exclusion of a relatively few households. However, it is also likely to significantly reduce the unexplained variance, ince the included variables are not expected to account for much of the variation in the amount of electricity consumed in heating a pool. As long as excluding the variable would not favor the specification with one weather variable over the specification with the other weather variable, such exclusions will not affect the validity of the test. In short, the objective is to obtain a good test of the incremental value of the weather station data rather than to explain energy consumption among the widest range of energy consumers.

The original PNWRES sample consisted of 4,703 observations on residential housing units that were individually metered to measure their consumption of electricity and natural gas. Meteorology data (heating and cooling degree days) were unavailable for 634 of these observations; after these were excluded, 4,069 observations remained. The next step in creating a relevant subsample was to exclude respondents not using electricity or natural gas most of the time for purposes of space heating. After this group was excluded, a subsamp le of 2,329 households remained. 
From the remaining subsample we next eliminated respondents from additional categories in accordance with the criteria discussed above. These additional eliminations are presented in Table 1 , which shows the PNWRES variable number, the description of the variable being excluded, the reason for excluding the variable, and the number of respondents among the 2,329 households falling into the restricted category. The numbers in the last column may be mutually inclusive.

The reasons for excluding some of the variables requires some elaboration. The design energy use of an unconventional residence, such as a houseboat, is difficult to characterize, particularly if the survey data do not indicate what makes the residence unconventional. Thus, unconventional residences were removed from the sample. We also removed respondents who might have moved into their residences between December 1981 and January 1983, the period of analysis. It was unlikely that they were in residence during all of their first billing period, which would affect their use of appliances and hot water. After the exclusions indicated in Table 1 were made, 1,604 households remained in the sample.

Some additional screening of variables was performed before regressions were run on the statistical model. Respondents who did not report their household income (V364) were excluded, as were those for which there were no heating degree days reported within the 12-month sample period selected for this study. (Respondents with no heating degree days reported within the 20month period covered by the 1983 PNWRES had been excluded earlier.) Additional1y, respondents who did not know the percentage of their basement that was heated during the heating. months were assumed to have an unheated basement. 
TABLE 1. Additional Exclusions from Data Set

\begin{tabular}{|c|c|}
\hline $\begin{array}{l}\text { PNWRES } \\
\text { Variable } \\
\text { Number }\end{array}$ & Description \\
\hline 5 & $\begin{array}{l}\text { Not a mobile home, SF Residence } \\
\text { or building with } 2 \text { or more units }\end{array}$ \\
\hline 7 & $\begin{array}{l}\text { Not a mobile home or building } \\
\text { with } 5 \text { or more units, not de- } \\
\text { tached, not attached on } 1 \text { or } 2 \\
\text { sides. }\end{array}$ \\
\hline 20,21 & $\begin{array}{l}\text { First moved into residence } \\
\text { after } 12 / 81\end{array}$ \\
\hline $\begin{array}{r}164 \\
166\end{array}$ & $\begin{array}{l}\text { Fuel type used most of time for } \\
\text { space heating was changed since } \\
\text { g/81 }\end{array}$ \\
\hline $\begin{array}{r}297 \\
300\end{array}$ & $\begin{array}{l}\text { Swimming pool heated with } \\
\text { electricity or natural gas }\end{array}$ \\
\hline 316 & $\begin{array}{l}\text { Utility bilis include charges } \\
\text { for electricity not relating } \\
\text { to living quarters }\end{array}$ \\
\hline 317 & $\begin{array}{l}\text { Utility bills include charges } \\
\text { for natural gas not relating } \\
\text { to living quarters }\end{array}$ \\
\hline $\begin{array}{r}366 \\
368\end{array}$ & $\begin{array}{l}\text { Electricity used for water } \\
\text { heating or space heating } \\
\text { included in rent }\end{array}$ \\
\hline $\begin{array}{r}376 \\
378\end{array}$ & $\begin{array}{l}\text { Natural gas used for water } \\
\text { heating or space heating } \\
\text { incTuded in rent }\end{array}$ \\
\hline
\end{tabular}

\begin{tabular}{lc} 
Reason for Excluding & $\begin{array}{c}\text { Number } \\
\text { in } \\
\text { Category }\end{array}$ \\
$\begin{array}{ll}\text { Unconventional residence } \\
\text { Unconventional residence }\end{array}$ & 42 \\
& \\
$\begin{array}{l}\text { Cannot adjust for appliance } \\
\text { use in first billing period }\end{array}$ & 432 \\
$\begin{array}{l}\text { To reduce unexplained } \\
\text { variance }\end{array}$ & 75 \\
$\begin{array}{l}\text { To reduce unexplained } \\
\text { variance }\end{array}$ & 16 \\
$\begin{array}{l}\text { To reduce unexplained } \\
\text { variance }\end{array}$ & 133 \\
$\begin{array}{l}\text { To reduce unexplained } \\
\text { variance }\end{array}$ & 134 \\
$\begin{array}{l}\text { To reduce unexplained } \\
\text { variance }\end{array}$ & 24 \\
$\begin{array}{l}\text { To reduce unexplained } \\
\text { variance }\end{array}$ & 17 \\
& \\
\hline
\end{tabular}




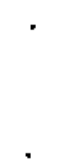




\subsection{ESTIMATION RESULTS}

As discussed in Chapter 2.0, we are estimating a statistical relationship of the form

$$
C E=a_{0}+a_{1} S H+a_{2} S C+a_{3} A P+a_{4} W H+a_{5} C R+e
$$

where $C E=$ household consumption of electricity (natural gas)

$\mathrm{SH}=$ design space heating requirements of the housing unit

$S C=$ design space cooling requirements of the housing unit

$A P=$ electricity (natural gas) consumption of appliances

$W H=$ electricity (natural gas) consumption for water heating

$C R=$ consumer response submodel.

The constants $a_{0}, \ldots, a_{5}$ are parameters to be estimated and $\underline{e}$ is a stochastic disturbance term distributed $\mathrm{N}:\left(0, \sigma^{2}\right)$, with zero covariances. SH, SC and WH are independent variables that are computed within the submodels. As discussed earlier, $\mathrm{SH}$ and $\mathrm{SC}$ are based on engineering computations, and $\mathrm{WH}$ is computed by applying the PNWRES data to variables used in a statistical relationship estimated on the RECS data by Latta (1983). SC is computed only for dwelling units with central air conditioning, an evaporative swamp cooler, or a heat pump. Room air conditioners were considered with other appliances. AP is expanded to inciude individual appliances and $C R$ is expanded to include the two consumer response variables, energy price and household income.

All of the variables except price and income are measured in average $B \mathrm{tu} / \mathrm{hr}$; price and income are measured in dollars. The model is estimated for electricity and natural gas, and for meteorological station data and climatic division data. In addition, the model is estimated for a subset of the sample (referred to below as the restricted sample) that includes only households with a weather station located within their zip code area.

The purpose of the restricted sample is to construct a more stringent test for the climatic division data. By restricting the sample to households with a weather station within their zip code area, we almost certainiy reduce the average distance between the housing units and their corresponding weather stations. This means that the weather station data should more closely approxi- 
mate the microclimate around the housing unit, compared with the data from the unrestricted sample. On the other hand, there is no reason to believe that the restricted sample will perform better than the unrestricted sample when the climatic division data are used. The test will be for the climatic division data to perform as well as the station data with the restricted sample. If for this resricted sample we cannot reject the null hypothesis that the climatic division data perform as we 3$]$ as the station data, then the case is even stronger that we should not reject the null hypothesis for the unrestricted sample.

\subsection{REGRESSION RESULTS}

All of the variables discussed previously were included in an initial regression on a subsample (99 observations) to establish which variables were likely to be of significance in explaining electricity and natural gas consumption. The number of independent variables was reduced according to the following criteria: 1) variables that shouid be included on theoretical grounds were included, even if their coefficients were not statisticaliy different from zero; and 2) if any one of a set of dummy variables was retained, then all of the dummy variables in the set were retained regardless of significance.

Equation specifications with natural logarithms of the energy price and income variables did not measurably improve the statistical significance of the regression, and so the simple linear model was retained. Because the space heating, space cooling, water heating, and appliance and iighting components of the mode? are additive in the ir simple form, logarithmic transformations were not evaluated. The dependent and independent variables used in the regressions are identified in Table 2 for convenience.

The dummy variables MOB, SFA1, SFA2, MFA1, MFA2, MFD and MF5 have already been incorporated into the space heating, space cooling and water heating submodels. Therefore, their presence in a regression equation should be interpreted as affecting only the appliance and lighting variable and the consumer response variables. The variables TALE and TALG, which give the number of months of billing data reported for each respondent, are used to adjust appliance and water heater use. The space heating and space cooling modeis do not need to be adjusted since heating and cooling degree days are 


\section{TABLE 2. Regression Variables}

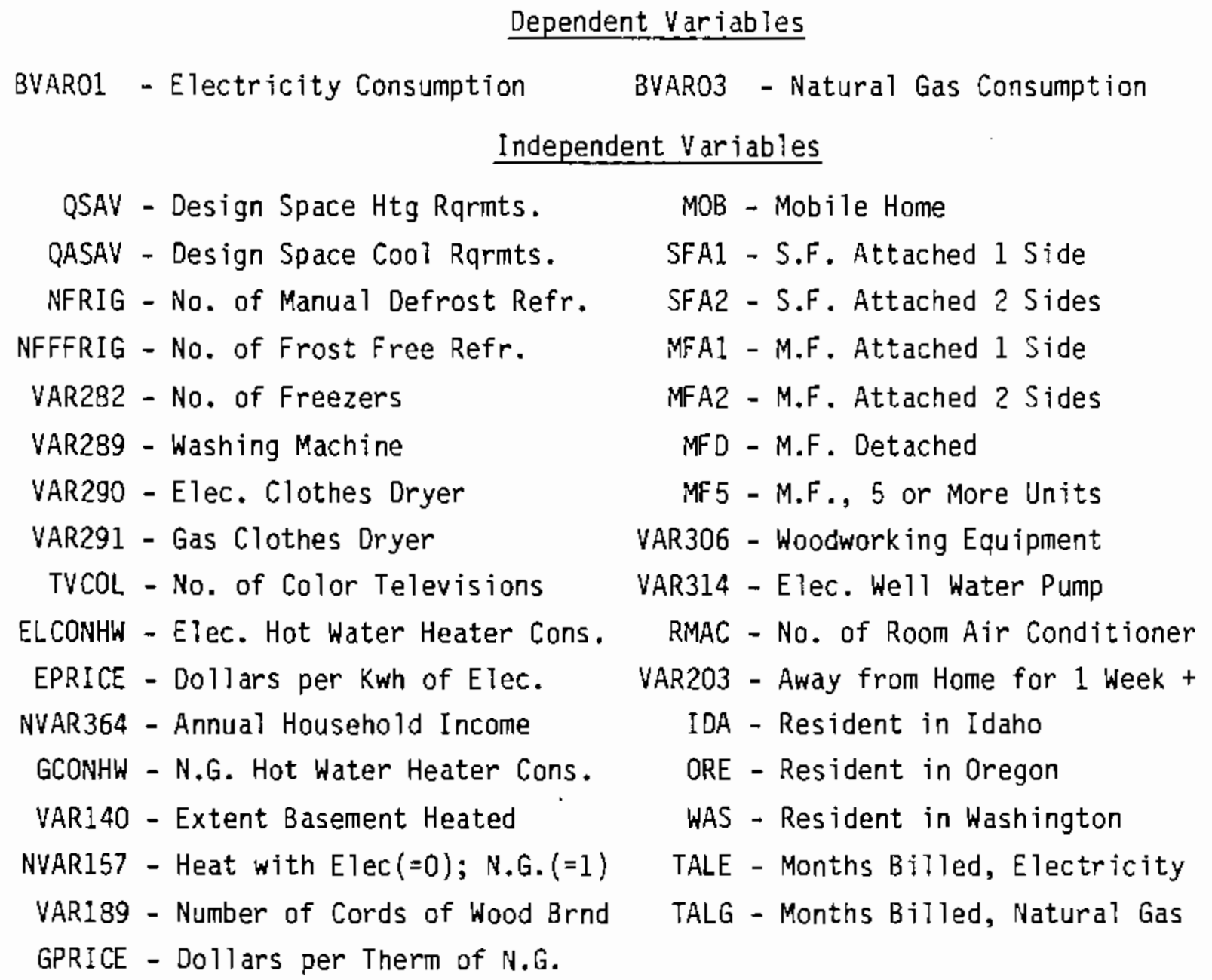

reported only for months in which billing data are also reported. In the regression results, several variable names begin with the letter $I$. This indicates that the original variable has been adjusted by multiplying it by TALE/12 or TALG/12, for electric and gas appliances, respectively.

The regression results are reported in Tabies 3 through 10 , followed by a discussion of the statistical test of the null hypothesis that the regressions using meteorological station data are not statistically different from regressions using climatic division data. 
Table 3 presents the results for the electricity consumption regression run on the full sample with meteorological station data. All of the variables except QASAV, TNFRIG, TNFFFRIG, TVAR289, TVAR290, SFA2, MFA2, MFD and VAR203 are significant at the $95 \%$ confidence level or better, and QASAV, TNFFFRIG, MFA2 and MFD are significant at a 90\% confidence level. All of the coefficients have the expected sign except SFA1, MFD, and TRMAC. (The signs of SFAI and MFD are expected to be negative because these types of housing units, relative to single-family detached, are likely to be smaller and have smaller major appliances.) SFAl is statistically significant, and the reason for the positive coefficient is not clear. The elasticity of electricity consumption with respect to the price of electricity is, at the mean values of the variables, equal to -0.22 , and the elasticity with respect to income is 0.06 .

Table 4 presents the results for the natural gas consumption regression run on the full sample with meteorological station data. All of the variables except TGOV, MOB, SFA2, MFA1, MFD, and MF 5 are significant at the $95 \%$ confidence level or better, and only the last four are not significant at a $90 \%$ confidence level. All of the coefficients have the expected sign except TGOV, SFA1, MFA2, and MF5. TGOV is significant at the $90 \%$ confidence level, and SFAl and MFA2 are highly significant. The elasticity of natural gas consumption with respect to the price of natural gas is, at the mean values of the variables, equal to -0.11 , and the elasticity with respect to income is 0.14 .

Table 5 presents the resuits for the electricity consumption regression run on the full sample with climatic division data. Ail of the variables except QASAV, TNFRIG, TVAR289, TVAR290, SFA2, MFA2, MFD and VAR203 are significant at the $95 \%$ confidence level or better, while MFA2 is significant at the 90\% confidence level. All of the coefficients have the expected sign except SFAl, MFD and TRMAC; both SFA1 and TRMAC are statistically significant. The elasticity of electricity consumption with respect to the price of electricity is, at the mean values of the variables, equal to -0.23 , and the elasticity with respect to income is 0.06 .

Table 6 presents the results for the natural gas consumption regression run on the full sampie with climatic division data. All of the variables except TGOV, MOB, SFA2, MFA1, MFD, MF5, and TVAR291 are significant at the $95 \%$ 
TABLE 3. Electricity Consumption: [leteorolonical Stations, Full Sample

ANALYSI: UF VAFIANCt:

\begin{tabular}{|c|c|c|c|c|c|}
\hline SilukCE & $13 \mathrm{~F}$ & $\begin{array}{l}\text { SUM OPF } \\
\text { SUIJARES }\end{array}$ & $\begin{array}{l}\text { MEAS: } \\
\text { SOUAKE: }\end{array}$ & F VALlif & $P+0 B>F$ \\
\hline 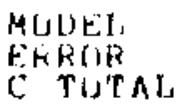 & $\begin{aligned} 123 \\
1227\end{aligned}$ & $\begin{array}{r}4867131440 \\
7942685412 \\
16829816859\end{array}$ & $\begin{array}{r}360397019 \\
0596915\end{array}$ & $58.5 / 2$ & 0.0001 \\
\hline $\begin{array}{l}R 610 \\
\text { DEF } \\
\text { C. V }\end{array}$ & $\begin{aligned} & M S E: \\
& \text { YEAI }\end{aligned}$ & $\begin{array}{l}2509.446 \\
1463: 747 \\
34.32032\end{array}$ & $\begin{array}{l}R=S U U A R E \\
A O J \quad R=S I\end{array}$ & $\begin{array}{l}0.5261 \\
0.5190\end{array}$ & \\
\hline
\end{tabular}

DEP VARIABIF: BVAKOI

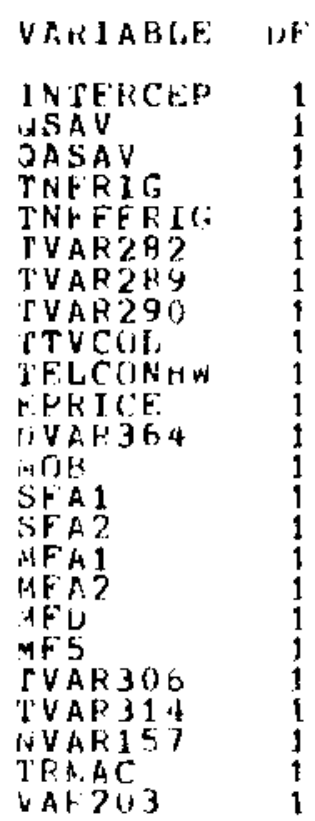

PARAMETER

5005.532

0.176265 ?

1. 9318526

72.66588

378.2149

30.4712

194.9454

311.4436

451.4257

- 531474

$\begin{array}{r}-53147 \\ \hline 2217453\end{array}$

914.6966

व39.1414

$-72 \mathrm{~h} .092$

$-986.94$

$-1376: 02$

$2625.22 \mathrm{~B}$

$-1714.87$

60 3.3504

$605.1) 91$

$-42.2 y .27$

-401.808
-110.674
STA VUAKD

F.RेUI

0.02213275

0.4458707

211.4321

124761

379.7999

325.2396

142.1732

7613.04

0.004762042

224.2457

870.1265

+50.t726

$1498: 413$

438.5577

1.4 .4342

2211.4345

251.3594

169
395
9
Fl) HO:

$$
\begin{array}{r}
12.071 \\
7.964 \\
1.666 \\
0.343 \\
1.667 \\
3.114 \\
0.513 \\
0.958 \\
3.170 \\
19.397 \\
-6.916 \\
4.656 \\
4.079 \\
2.285 \\
-6.835 \\
-2.191 \\
-1.658 \\
1.752 \\
-3.916 \\
3.163 \\
-2.745 \\
-16.426 \\
-2.347 \\
-1.231
\end{array}
$$

PRUB $>11$

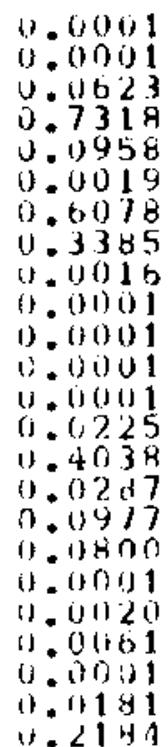


TABLE 4. Natural Cas Consursption: ileteorolonical Stations, Full Sar.ple

ANALYSIS OF VARIAMCE.

\begin{tabular}{|c|c|c|c|c|c|}
\hline Sabert: & $\mathrm{Dr}$ & $\begin{array}{l}\text { SWiA UF } \\
\text { SQUARES }\end{array}$ & $\begin{array}{l}\text { MEAAN } \\
\text { SUIJARE: }\end{array}$ & F VAlite & $\mathrm{PHOH}>\mathrm{r}$ \\
\hline $\begin{array}{l}\text { MUDET, } \\
\text { GRER } \\
\text { C. TISAI. }\end{array}$ & $\begin{array}{r}19 \\
12138 \\
1227\end{array}$ & $\begin{array}{r}27272054648 \\
6004421372 \\
33277076020\end{array}$ & $\begin{array}{r}1435402576 \\
4970547\end{array}$ & $2 \mathrm{db.7b?}$ & 0.0001 \\
\hline $\begin{array}{l}\text { RuIji } \\
\text { DEP } \\
C . V .\end{array}$ & $\begin{array}{l}\text { NS } \\
\text { HA is }\end{array}$ & $\begin{array}{l}2229.472 \\
2008: 658 \\
110.9931\end{array}$ & $\begin{array}{l}K=S U U A K E \\
A(J) K=S U\end{array}$ & $\begin{array}{l}0.4196 \\
0.4167\end{array}$ & \\
\hline
\end{tabular}

DIP VARIABISE: BVAROB

$\omega$

\begin{tabular}{|c|c|c|}
\hline VAKIABLE. & は上 & $\begin{array}{l}\text { PARAMETEKK } \\
\text { ESTIMA IF }\end{array}$ \\
\hline 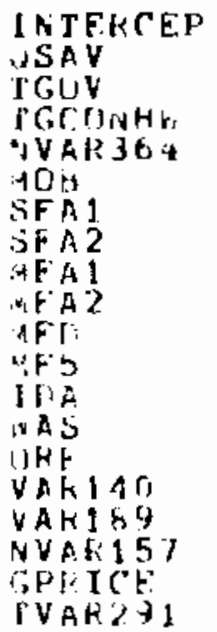 & $\begin{array}{l}1 \\
1 \\
1 \\
1 \\
1 \\
1 \\
1 \\
1 \\
1 \\
1 \\
1 \\
1 \\
1 \\
1 \\
1 \\
1 \\
1 \\
1 \\
1 \\
1\end{array}$ & 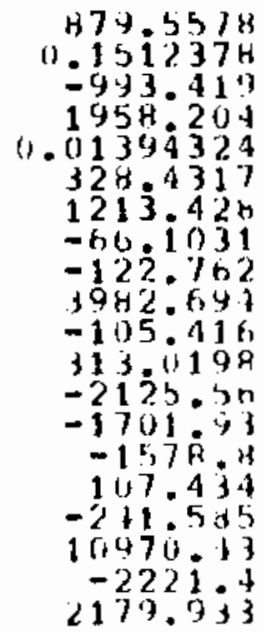 \\
\hline
\end{tabular}

\begin{tabular}{|c|}
\hline $\begin{array}{r}\text { STANUA } \\
\text { ENIR }\end{array}$ \\
\hline 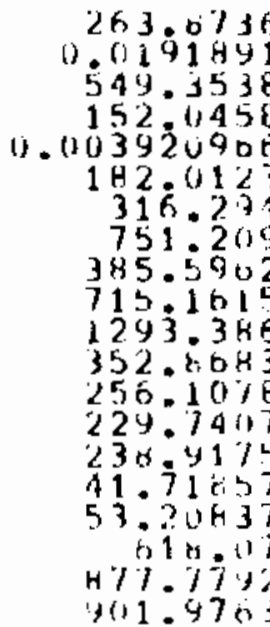 \\
\hline
\end{tabular}

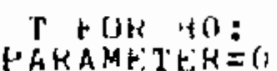

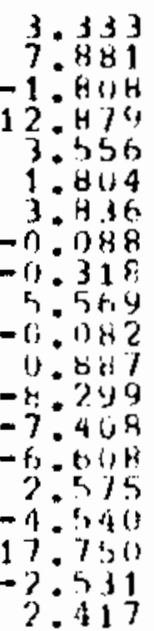

$P P_{i J H}>1.1$

1). 0009

1.0001

- 1708

i. . 0004

i). 0714

U. $)(3) 1$

0.9299

0.7503

1). 1 011

0.4351

i. 3752

i) (i) 01

11. (1) 1

1)

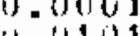

(1) (11) 1

(1) 11001

1). 110101

v. 11 bh 
TABLE 6. Natural âs Consuription: Climate Zones, Full Sample

\begin{tabular}{|c|c|c|c|c|c|}
\hline SulleCet & DF & $\begin{array}{l}\text { SIJA OF } \\
\text { SUIJARES }\end{array}$ & $\begin{array}{l}\text { MCAN } \\
\text { SUUARE: }\end{array}$ & F VALUE & $P K \cap k>F$ \\
\hline 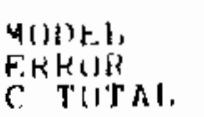 & $\begin{array}{r}14 \\
1254 \\
127\end{array}$ & $\begin{array}{r}30026091684 \\
6492052318 \\
36518144002\end{array}$ & $\begin{array}{r}1580320615 \\
5177075\end{array}$ & 305.254 & 0.0001 \\
\hline $\begin{array}{l}\text { Pugr } \\
\text { nt:p } \\
\text { C. . }\end{array}$ & I MEE & $\begin{array}{l}2275.319 \\
2193 \div 421 \\
103.733 \mathrm{H}\end{array}$ & $\begin{array}{l}R-S U U A F r \\
A D J R=S U\end{array}$ & $\begin{array}{l}0.8222 \\
0.8195\end{array}$ & \\
\hline
\end{tabular}

DEPP VARIAGIAT: BVAKIIS

$\omega$

\begin{tabular}{|c|c|c|}
\hline VARIAELF. & $\omega F$ & $\begin{array}{l}\text { PARAMESFR } \\
\text { ESTINASF }\end{array}$ \\
\hline 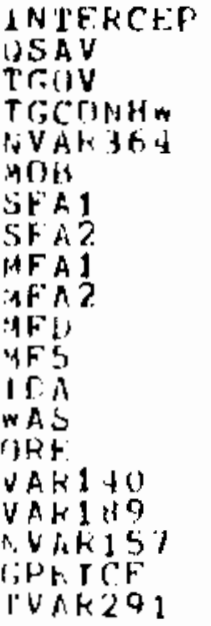 & $\begin{array}{l}1 \\
1 \\
1 \\
1 \\
1 \\
1 \\
1 \\
1 \\
1 \\
1 \\
1 \\
1 \\
1 \\
1 \\
1 \\
1 \\
1\end{array}$ & $\begin{array}{r}953.3972 \\
01472976 \\
-1053.23 \\
1636.217 \\
0.01405289 \\
347.4316 \\
1248.934 \\
-52.9643 \\
-140.941 \\
1905.079 \\
-169.371 \\
328.751 \\
=2200.38 \\
-1349.48 \\
-1059.18 \\
1059773 \\
-236.45 \\
11330.27 \\
-7173.32 \\
1360.59\end{array}$ \\
\hline
\end{tabular}

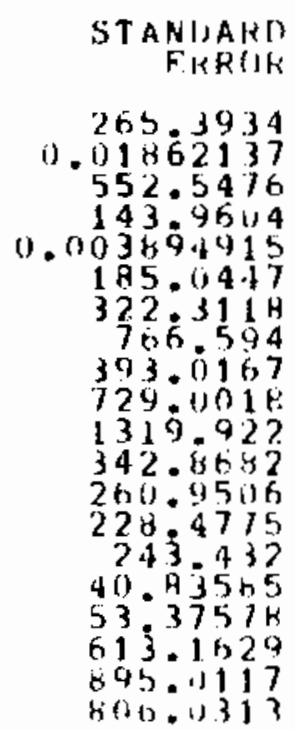

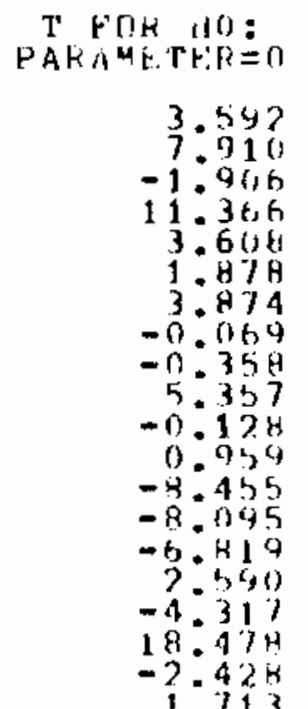

PRUA > II

1).0003

0.0001

0.0569

0.0001

0.0003

0.0607

0.0001

0.7201

1) กnu 1

(1. 4979

(1. 8979

0.3378

.

0.0019

- 000

0.0097

i) 0000

i) (1) 11

1). 0153 
confidence level or better, and TGOV, MOB and TVAR291 are significant at a 90\% confidence level. All of the coefficients have the expected sign except TGOV, SFA1, MFA2, and MF5. TGOV is significant at the $90 \%$ confidence leve1, and SFA and MFA2 are highly significant. The elasticity of natural gas consumption with respect to the price of natural gas is, at the mean values of the variabies, equal to -0.11 , and the elasticity with respect to income is 0.13 .

Table 7 presents the resuits for the electricity consumption regression run on the restricted sample with meteorological station data. All of the variables except TNFRIG, TVAR290, SFA1, SFA2, MFA1, MFA2, MFD and TRMAC are significant at the $95 \%$ confidence level or better; of the exceptions, TNFRIG and TRMAC are significant at the $90 \%$ confidence level. A 11 of the coefficients have the expected sign except SFAI and RMAC. The elasticity of electricity consumption with respect to the price of electricity is, at the mean values of the variabies, equal to -0.20 , and the elasticity with respect to income is 0.04 .

Table 8 presents the results for the natural gas consumption regression run on the restricted sample with meteorological station data. All of the variables except TGOV, MOB, SFA2, MFA1, MFD, MF5, VAR140, GPRICE and TVAR291 are significant at the $95 \%$ confidence level or better; none of these are significant at a $90 \%$ confidence level. All of the coefficients have the expected sign except TGOV, SFA1, MFA2 and MF5; SFA1 and MFA2 are highly significant. The elasticity of natural gas consumption with respect to the price of natural gas is, at the mean values of the variables, equal to -0.04 , although the price coefficient is not significant; and the elasticity with respect to income is 0.15 .

Table 9 presents the results for the electricity consumption regression run on the full sample with climatic division data. All of the variables except TNFRIG, TVAR290, MOB, SFA1, SFA2, MFA1, MFA2, MFD and TRMAC are significant at the $95 \%$ confidence level or better, and TNFRIG, MOB, MFA2 and TRMAC are significant at the $90 \%$ confidence level. All of the coefficients have the expected sign except SFAI and TRMAC, neither of which is statisticaliy significant. The elasticity of electricity consumption with respect to the price of electricity is, at the mean values of the variables, equal to -0.21 , and the elasticity with respect to income is 0.05 . 
TABLE 7. Electricity Consurntion: ileteorological Stations, Restricted Sample

ANALYSIS I,F VARIANCE:

\begin{tabular}{|c|c|c|c|c|c|}
\hline Sullect: & $\mathrm{DF}$ & $\begin{array}{c}\text { SUM UF } \\
\text { SUTHARTIS }\end{array}$ & $\begin{array}{l}\text { MEAN } \\
\text { SUIARE. }\end{array}$ & $F \vee A I_{1}, J+$ & $P+\mathrm{O}_{6}>\mathrm{R}$ \\
\hline $\begin{array}{l}\text { M(J)EI, } \\
\text { FRROR } \\
\text { C TOTAL }\end{array}$ & $\begin{array}{r}23 \\
655 \\
68 x\end{array}$ & $\begin{array}{l}5456452071 \\
3529158667 \\
9486010738\end{array}$ & $\begin{array}{r}254993066 \\
5307006\end{array}$ & $4 \mathrm{H} . \mathrm{AOC2}$ & 0.0401 \\
\hline $\begin{array}{l}k(1)] \\
\text { brep } \\
C . V\end{array}$ & $\begin{array}{r}\text { MSE } \\
\text { MEAN }\end{array}$ & $\begin{array}{l}2303.694 \\
7226.241 \\
31.87956\end{array}$ & $\begin{array}{l}R=S U H A R E \\
\Lambda \cup J \quad R=S O\end{array}$ & $\begin{array}{c}1.0240 \\
0.0151\end{array}$ & \\
\hline
\end{tabular}

DEF VARIABIF: BVAROS

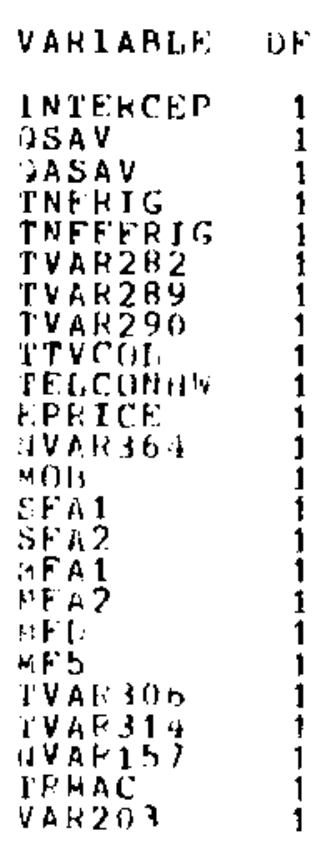

$$
\begin{aligned}
& \text { PARAMETER } \\
& \text { ESTI IMA T' } \\
& 3211.684 \\
& \text { 1. } 497761 \\
& 425.412 \\
& 425.412 \\
& 911.6522 \\
& 402.2391 \\
& 904.7459 \\
& 283.1406 \\
& \text { 933.6929 } \\
& 1.514084 \\
& \text { (1) } 01493690 \\
& 019.6856 \\
& \angle 70.0403 \\
& -177.936 \\
& -679.436 \\
& -1253.32 \\
& -635.67 \\
& -1171.77 \\
& 742.8127 \\
& 072.5100 \\
& -3679.55 \\
& -322.396
\end{aligned}
$$

$$
\begin{array}{r}
\text { STANDAKD) } \\
\text { E.RR(JR }
\end{array}
$$

555.4841

0.02905156

$0.496 y 396$

256.8716

268.2492

14.425

448.5641

$374.39 \mathrm{dA}$

172.574 .7

1945

0.005745222

$300.031 \mathrm{~h}$

444.0508

$793 \cdot 4505$

965.6765

1649501

5649.501

$234: 7217$

285.7637

$<804123$

142.675
TAOK HO:

5.777

4. 333

3.019

1.650
3.399

?. 854

$2: 017$

$0.75 t$

4.032

$-5: 244$

2.600

?. $\operatorname{th} 1$

0.600

$-0.221$

- 1 - ?yq

-1.248
-10.385

$-2.309$

3.105

$2 \cdot 3+3$

$-12.513$

$-2.294$
PRIJI > I I

0.0001

v. 0001

1). 0027

0.0982

0.0007

11.0043

0.0411

0.4496

(). (1) (;) 1

6.00 .11

). (10)1

1). 0035

1). 0347

0.5433

11. $42<7$

0.1945

11. 1049

1.7001

t) 0213

i)

11. (1) 001

i. 0.947

). 0221 
TABLE 3. llatural Gas Consumption: lleteorological Stations, Restricted Sar:ple

ANALYSIS OF VARIANCE

\begin{tabular}{|c|c|c|c|c|c|}
\hline SHIHCR. & $D F$ & $\begin{array}{l}\text { SUUA (IF } \\
\text { SOUARES }\end{array}$ & $\begin{array}{l}\text { MEAAH } \\
\text { StrUARE. }\end{array}$ & f. $V$ nI, IJF & $P K(n)>F$ \\
\hline 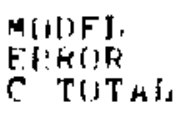 & $\begin{array}{r}14 \\
669 \\
6 \times 8\end{array}$ & $\begin{array}{r}18525363635 \\
4544743320 \\
23070106955\end{array}$ & $\begin{array}{r}975019139 \\
6793336\end{array}$ & 143.526 & $0.0 \cup 01$ \\
\hline 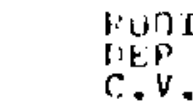 & MSF: & $\begin{array}{l}26106.403 \\
2425.559 \\
107.4558\end{array}$ & $\begin{array}{l}R=S U I J A R E \\
A D J R=S O\end{array}$ & $\begin{array}{l}0.8030 \\
0.7974\end{array}$ & \\
\hline
\end{tabular}

DEP VARIAHTE: BVAKO3

$\omega$

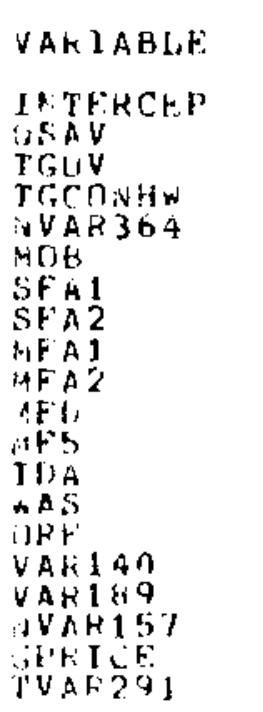

$$
\begin{aligned}
& \begin{array}{l}
\text { PARAMETER } \\
\text { ESTIMATE. }
\end{array} \\
& 1770.654 \\
& \text { 6. } 1760213 \\
& -644.429 \\
& 2319008 \\
& \text { 1. } 0175 i 425 \\
& 162.8361 \\
& 1490.441 \\
& -234.413 \\
& -243.406 \\
& -479.879 \\
& 129.6898 \\
& -31351.27 \\
& -2674.03 \\
& -2550.63 \\
& \text { HO 26,6? } \\
& -355.0 .37 \\
& 9537.469 \\
& \begin{array}{r}
-830.911 \\
350.5704
\end{array}
\end{aligned}
$$

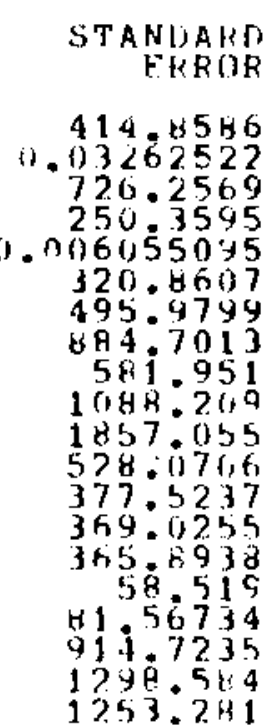

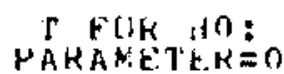

$4 \cdot 26 \mathrm{H}$

$5 \cdot 345$

$-0.067$

2. 0323

0.514

4.5118

$-0.205$

$-0.418$

4.1140

$-0.251$

8.24

$-7.216$

$-6.987$

1. 372

$-4.353$

$-0.11$

(j) .
$P R U H>1 H$

0.13001

- 375

0.375

i. 0036

i). 0034

i) 6120

(1). 1001

1).7911

0.659

i). 10011

i. 7462

1). $d(i 6)$

(10i)

(1)001

1.00iा

1. 0001

". 17116

(3.00)

11.0009

(1.. 4737

i. . 7796 
TABLE 9. Electricity Consumption: Climate Zones, Restricted Sample

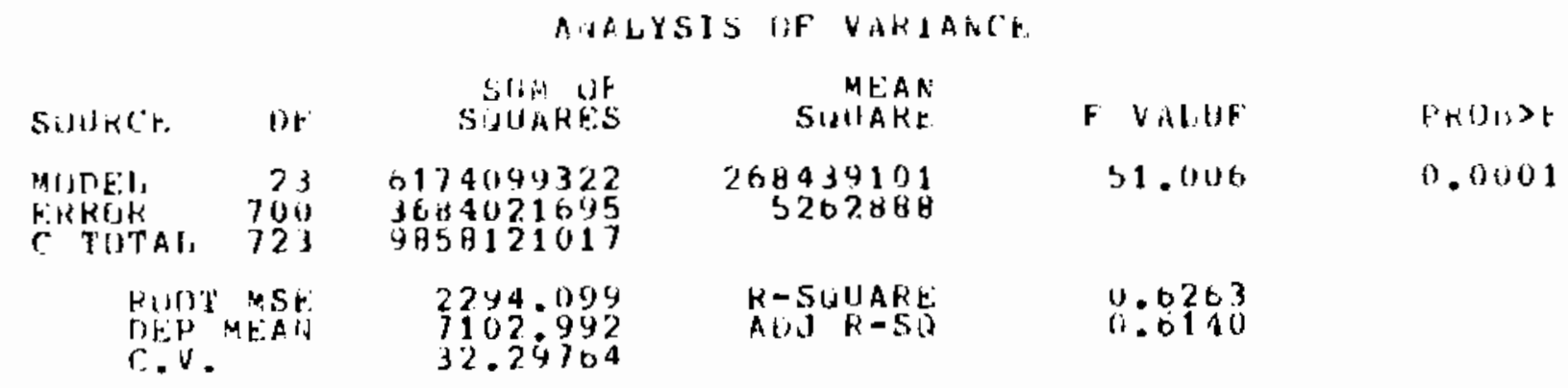

PAKAMEIER FISIMATES

DTP VAKIAHIR: HVAKCII

\begin{tabular}{|c|c|}
\hline $\begin{array}{l}\text { FAKAMRTEK } \\
\text { ESTIMASE. }\end{array}$ & $\begin{array}{c}\text { STAWUAKI } \\
\text { FEHUK }\end{array}$ \\
\hline 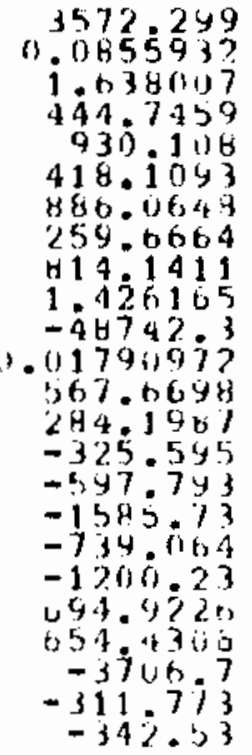 & 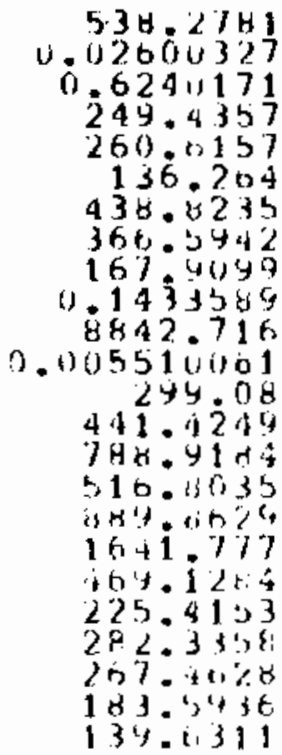 \\
\hline
\end{tabular}

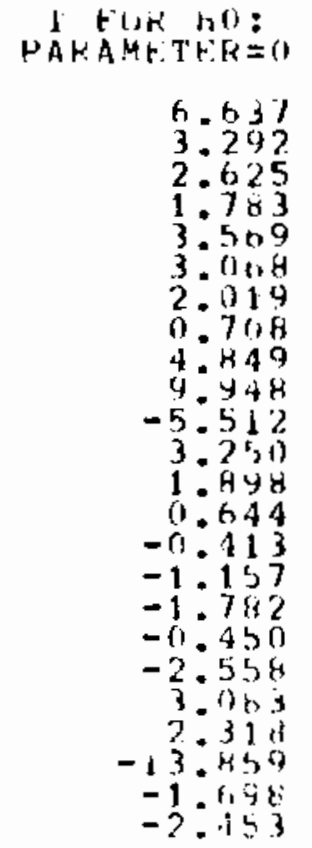

$P R U B>\left|I^{\prime}\right|$

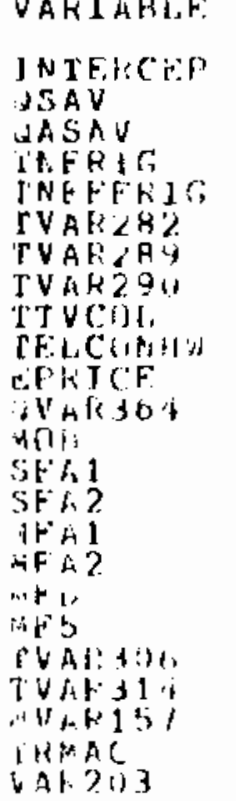

\begin{tabular}{|c|c|}
\hline$t r$ & $\begin{array}{r}\text { FAKAMETER } \\
\text { ESIJMARE. }\end{array}$ \\
\hline $\begin{array}{l}1 \\
1 \\
1 \\
1 \\
1 \\
1 \\
1 \\
1 \\
1 \\
1 \\
1 \\
1 \\
1 \\
1 \\
1 \\
1 \\
1 \\
1 \\
1 \\
1 \\
1 \\
1 \\
1 \\
1\end{array}$ & 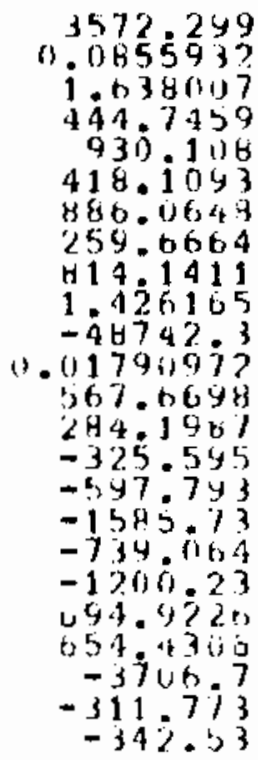 \\
\hline
\end{tabular}


Table 10 presents the results for the natural gas consumption regression run on the restricted sample with climatic division data. All of the variables except TGOV, MOB, SFA2, MFA1, MFD, MF5, VAR140, GPRICE and TVAR291 are significant at the $95 \%$ confidence level or better; none of these exceptions are significant at a $90 \%$ confidence level. A11 of the coefficients have the expected sign except TGOV, SFAI, MFA2, and MF5; SFAI and MFA2 are highly significant. The elasticity of natural gas consumption with respect to the price of natural gas is, at the mean values of the variables, equal to -0.09 , and the elasticity with respect to income is 0.14 .

\subsection{TEST OF EQUIVALENCE OF HEATHER DATA}

A test procedure described in Rao and Miller (1971; p.148ff), was used to determine if the regression based on weather station data was statistically equivalent to the regression based on climatic zone data. The null hypothesis, $H_{n}$, was that the two regressions were equivalent. The test statistic is

$$
F=\frac{\left(\operatorname{RSS}\left(H_{n}\right)-\operatorname{RSS}\left(H_{a}\right)\right) / R}{\operatorname{RSS}\left(H_{a}\right) /(N-K)}
$$

where RSS $\left(\mathrm{H}_{\mathrm{a}}\right)$ and RSS $\left(\mathrm{H}_{n}\right)$ are the residual sum of squares under the alternative and null hypotheses, respectively; $R$ is the number of restrictions imposed on the parameters, $N$ is the number of observations in the sample, and $K$ is the number of parameters estimated, including the intercept term.

RSS $\left(H_{n}\right)$ is obtained by running the regression on the pooled sample (climatic division data and weather station data). These regression results are presented for electricity consumption in Table 11 for the full sample and in Table 13 for the restricted sample. The corresponding regression results for natural gas are presented in Tables 12 and 14 . RSS $\left(H_{a}\right)$ is computed by adding the RSS for the separate regressions based on climatic division data and on weather station data. For the full sample test for electricity, we add the RSS from Tables 3 and 5. Applying the test, we have 
TABLE 10. Fatural Gas Consumtion: Clinate Zones, Restricted Sample

\begin{tabular}{|c|c|c|c|c|c|}
\hline \multirow[b]{2}{*}{ Soghere } & \multicolumn{4}{|c|}{ ANALYSIS IF VARIANCEE } & \multirow[b]{2}{*}{ FHOKS+ } \\
\hline & [1) & $\begin{array}{l}\text { SUM GF } \\
\text { SUIJARES }\end{array}$ & $\begin{array}{l}\text { MEAs } \\
\text { Swithes }\end{array}$ & F Valiug & \\
\hline 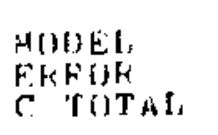 & $\begin{array}{l}14 \\
704 \\
723\end{array}$ & $\begin{array}{r}20906336167 \\
5105478064 \\
26011814251\end{array}$ & $\begin{array}{r}1100333484 \\
7252100\end{array}$ & 151.726 & 0.0001 \\
\hline $\begin{array}{l}\text { RUOT } \\
\text { nep } \\
C . V .\end{array}$ & MEE & $\begin{array}{l}2692.972 \\
2773.752 \\
97.08771\end{array}$ & $\begin{array}{l}R-S O U A R E \\
A I J \quad R=S,\end{array}$ & $\begin{array}{l}1.8037 \\
0.7984\end{array}$ & \\
\hline
\end{tabular}

DE.P VARIAHI.E: HVAKחB

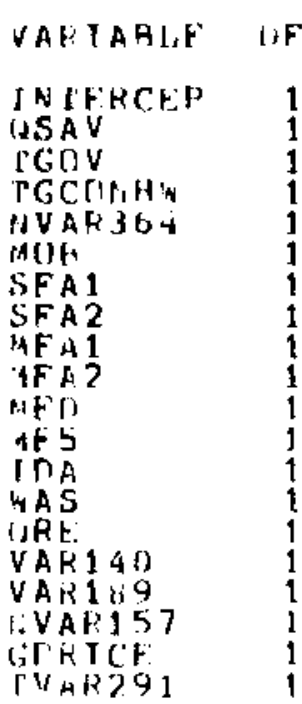

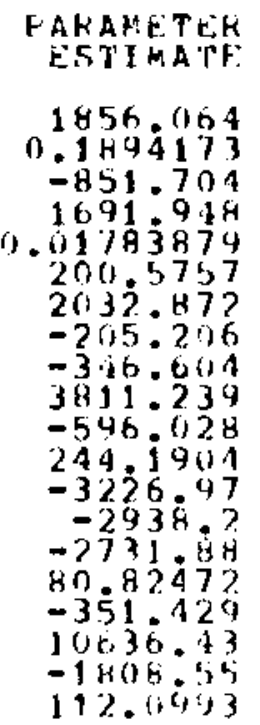

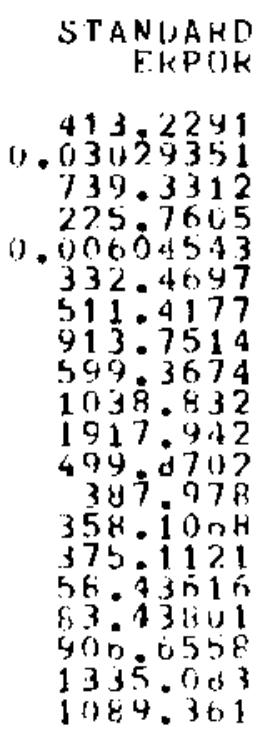

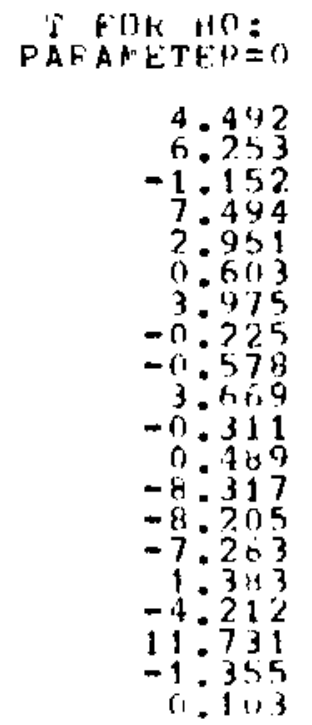

$f \cdot k 0 i s>\left|I^{\prime}\right|$

1). i) (1) 101

1).

0.01001

0.0033

1) 546

i). 0001

0.0224

0. 5033

0.0703

0.7501

i). 5,253

(1) bon

(). 001 i 1

6. 0101

i). 0 (1) 1

1). (1)

- 17 t

(1.) 91 b 
TABLE 11. Pooled Recression: Electricity, Full Sample

\begin{tabular}{|c|c|c|c|c|c|}
\hline \multicolumn{6}{|c|}{ ANALISIS UEF VAHIANCE. } \\
\hline Sollket: & $n \mathrm{E}^{\prime}$ & $\begin{array}{l}\text { SIIR OIF } \\
\text { SWIIARES }\end{array}$ & $\begin{array}{r}\text { ArAN } \\
\text { SuIAKE. }\end{array}$ & $F \quad V A l, L F$ & $P R O b>F$ \\
\hline 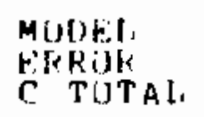 & $\begin{array}{r}23 \\
2476 \\
2501\end{array}$ & $\begin{array}{l}13391060037 \\
16395610432 \\
34786070469\end{array}$ & $\begin{array}{r}199011306 \\
6616469\end{array}$ & 120.852 & 0.0001 \\
\hline $\begin{array}{l}\text { Rugh } \\
\text { REP } \\
\text { C.V. }\end{array}$ & DEA & $\begin{array}{r}2572.25 \\
7506.871 \\
34.26527\end{array}$ & $\begin{array}{l}K-S W U A K C \\
A D J \quad R=S\end{array}$ & 0.5287 & \\
\hline
\end{tabular}

DEP VAKIAKLI: BVAKOI

\begin{tabular}{|c|c|}
\hline AKIAWLE: & i) $F$ \\
\hline 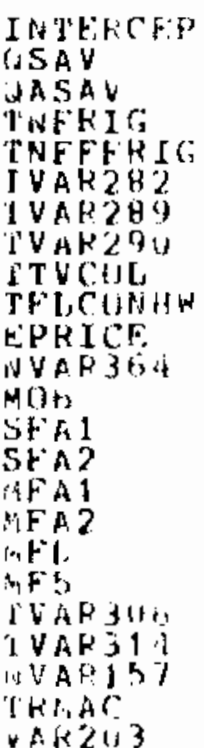 & \\
\hline
\end{tabular}

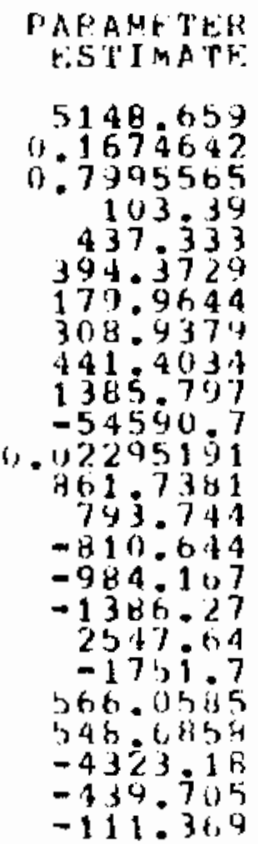

STANUARL

FiRUUK

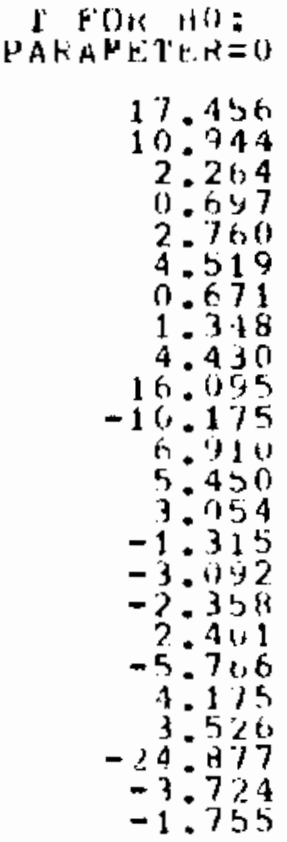

NRUH $>1$ II

$0.0(3))$

1). .0236

0.0236

0.0058

$0.0(i) 1$

0.5420

0.0001

a. bou 1

(1) (on)

U. o(bu)

Q. $0(0,0)$

0.00123

a. 1836

0.01020

a.? 184

J. $1106 \mathrm{i}$

(1)

(i)

(1)

1.01098 
TACLE 12. Pooled Regression: flatural Gas, Full Sample

\section{ANALYSIS IHF VARIANCE:}

\begin{tabular}{|c|c|c|c|c|c|}
\hline Susuker. & DF & $\begin{array}{l}\text { SUP UF } \\
\text { SUIIARES }\end{array}$ & $\begin{array}{l}\text { MEAAN } \\
\text { SUIJARE. }\end{array}$ & $F$ VAl, IE & $P \mathrm{~K}[]_{k}>r$ \\
\hline 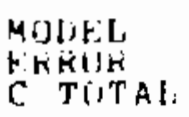 & $\begin{aligned} 14 \\
2442 \\
2501\end{aligned}$ & $\begin{array}{l}57303450901 \\
12513114652 \\
69816565553\end{array}$ & $\begin{array}{r}3015971100 \\
5041545\end{array}$ & 598.224 & $0.0(1) 1$ \\
\hline $\begin{array}{l}\text { RuO } \\
\text { Brep } \\
C . V\end{array}$ & $\begin{array}{l}M S E \\
N E A N\end{array}$ & $\begin{array}{l}2245.339 \\
2102: 738 \\
106.7817\end{array}$ & $\begin{array}{l}R=5(N) A R E \\
A D J \quad R=S O\end{array}$ & $\begin{array}{l}0.6208 \\
0.0194\end{array}$ & \\
\hline
\end{tabular}

DEY VAKIABLE: RVAKOS

$\stackrel{t a}{t}$

\begin{tabular}{|c|c|c|c|c|c|}
\hline VARIABLF. & ISF & $\begin{array}{l}\text { PAKAPIETEK } \\
\text { FETIAATE }\end{array}$ & $\begin{array}{c}\text { STAWUAKD } \\
\text { FRKLF }\end{array}$ & $\begin{array}{l}\text { THOK HOE } \\
\text { PARAMETEKSO }\end{array}$ & $\mathrm{PPUH}>\mathrm{I} \mathrm{H}$ \\
\hline 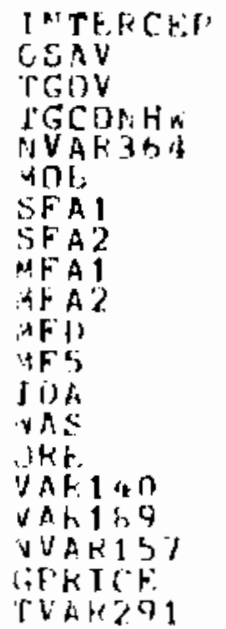 & $\begin{array}{l}1 \\
1 \\
1 \\
1 \\
1 \\
1 \\
1 \\
1 \\
1 \\
1 \\
1 \\
1 \\
1 \\
1 \\
1 \\
1 \\
1 \\
1 \\
1 \\
1\end{array}$ & 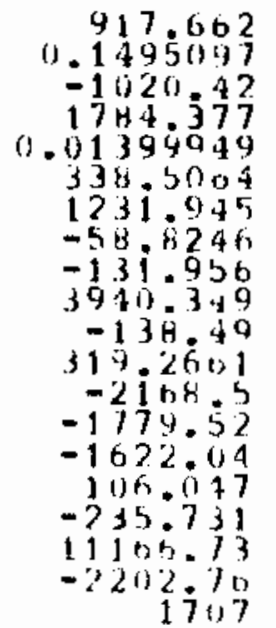 & 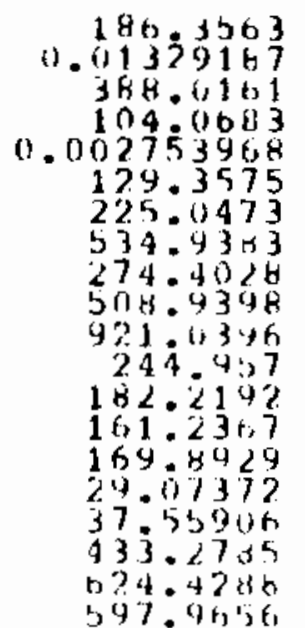 & 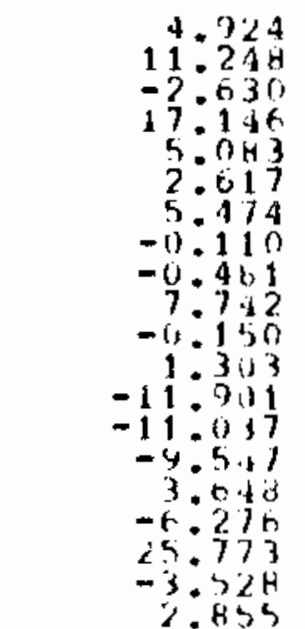 & 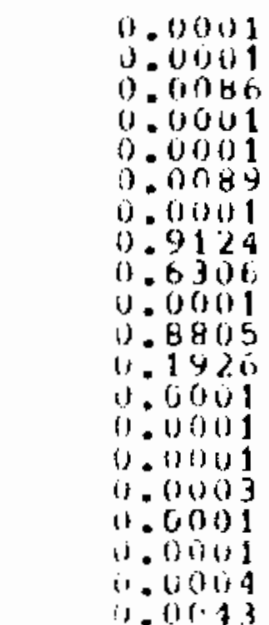 \\
\hline
\end{tabular}


TABLE 13. Pooled Regression: Electricity, Restricted Sample

ANALYSIS IF VARIANCL.

\begin{tabular}{|c|c|c|c|c|c|}
\hline sonker: & $1 \mathrm{HF}$ & $\begin{array}{l}\text { SUA UF } \\
\text { SCIIARES }\end{array}$ & $\begin{array}{l}\text { MEAN } \\
\text { SUIARE }\end{array}$ & F VAIIIt & $\mathrm{HKOH}>\mathrm{H}$ \\
\hline $\begin{array}{l}\text { MOCELI } \\
\text { ERRUF } \\
\text { C. TUTAL. }\end{array}$ & $\begin{array}{r}23 \\
1384 \\
1312\end{array}$ & $\begin{array}{r}12126147813 \\
7223346648 \\
19319494461\end{array}$ & $\begin{array}{r}527223818 \\
5200394\end{array}$ & 101.387 & 0.0001 \\
\hline $\begin{array}{l}k, n_{1} \\
n \in p \\
r . v .\end{array}$ & $\begin{array}{r}\text { ASE } \\
\text { NEAt }\end{array}$ & $\begin{array}{r}2280.437 \\
7163.09 \\
11.83594\end{array}$ & $\begin{array}{l}R-S O(1 A K E \\
A O, J R-S: d\end{array}$ & $\begin{array}{l}0.6207 \\
0.6205\end{array}$ & \\
\hline
\end{tabular}

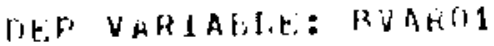

\begin{tabular}{|c|}
\hline VAKIABLF: \\
\hline 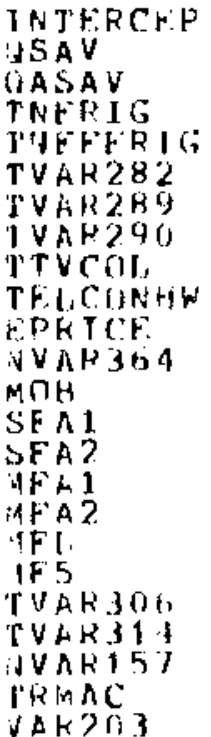 \\
\hline
\end{tabular}

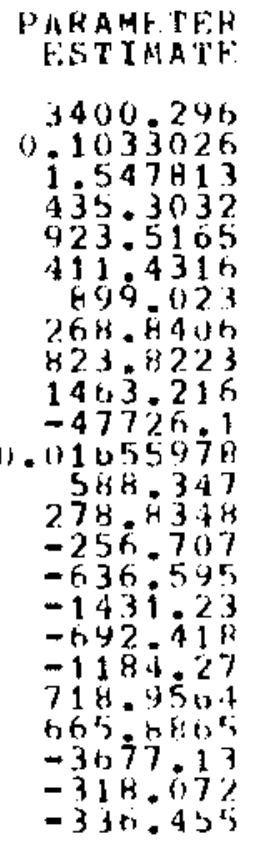

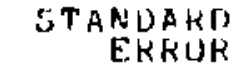

E.KRUR

363.351
0.01917184

0.01917184

ก. 3834903

177.4526

96.97423

3110715

259.778

119.3474

102.4643

44.477

1. $0039+311$

$211.2 \mathrm{~B} A$

554.9231

$364.077 \mathrm{H}$

t34. 1422

$1157.27 ?$

341.6129

$161: 2301$

199.1741

194.2531

131.563
+8.78176
I FOK HO:

8. 810

5. 388

4.036

1.982

4. $2+3$

2. 190

1.035

4.277

$7 \cdot 273$

$7 \cdot 643$

4.200

2.74

$-0.103$

$-1.746$

$-? .205$

$-0.6110$

- 3. 773

- 454

3.343
-14.930

$-2.41 \mathrm{f}$

$-3.4116$
PRIR > II

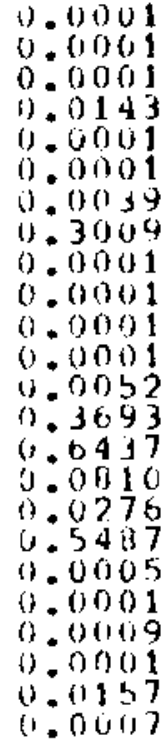


TABLE 14. Ponled Regression: Watural Gas, Restricted Sample

\begin{tabular}{|c|c|c|c|c|c|}
\hline \multirow[b]{2}{*}{ sulther. } & \multicolumn{4}{|c|}{ ANALYSIS UF } & \multirow[b]{2}{*}{ 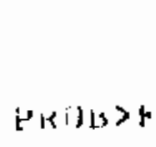 } \\
\hline & Dr & 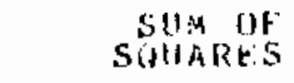 & $\begin{array}{r}\text { MAN } \\
\text { SWIAKE: }\end{array}$ & F VAI,UE & \\
\hline 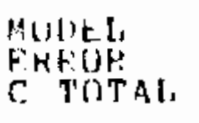 & $\begin{array}{r}14 \\
1343 \\
1412\end{array}$ & $\begin{array}{r}34445654554 \\
4679067826 \\
49124722385\end{array}$ & $\begin{array}{r}2076047082 \\
0,948362\end{array}$ & 298.789 & $0.0 \cup 01$ \\
\hline $\begin{array}{l}\text { RuOT } \\
\text { litep } \\
\text { C.V. }\end{array}$ & $\begin{array}{l}\text { MSF } \\
\text { MEAH }\end{array}$ & $\begin{array}{l}2635.975 \\
2603: 908 \\
101.2292\end{array}$ & $\begin{array}{l}R-S W \| A R E \\
A W J \quad R=S W\end{array}$ & $\begin{array}{l}0.4030 \\
0.8003\end{array}$ & \\
\hline
\end{tabular}

IPEP VARIARLI: EVAROS

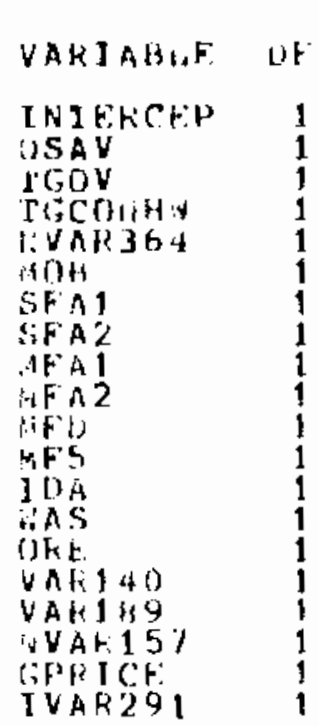

\begin{tabular}{|c|}
\hline $\begin{array}{l}\text { FARAMH'LR } \\
\text { FSTI I THE }\end{array}$ \\
\hline 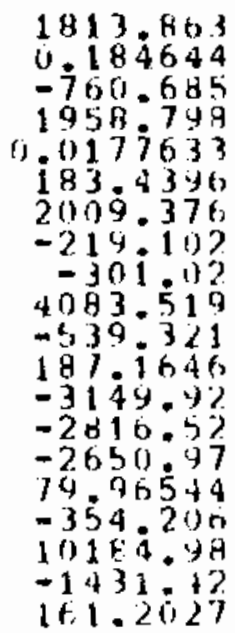 \\
\hline
\end{tabular}

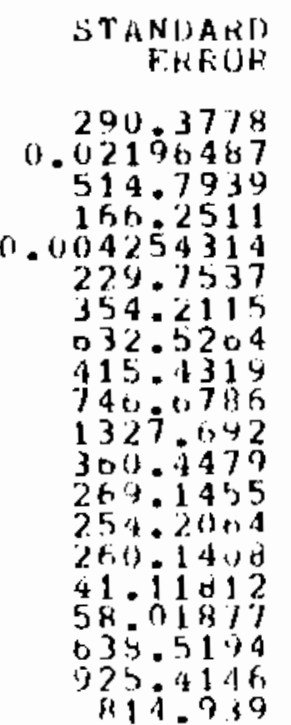

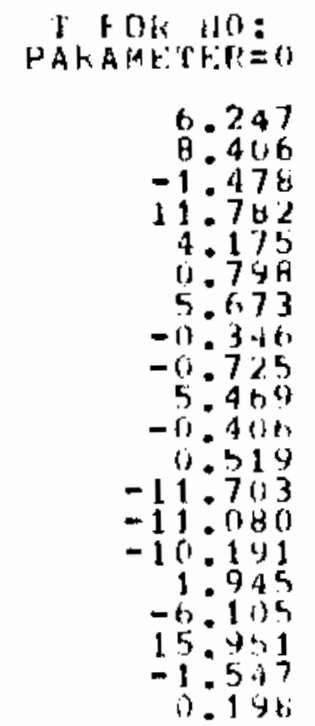

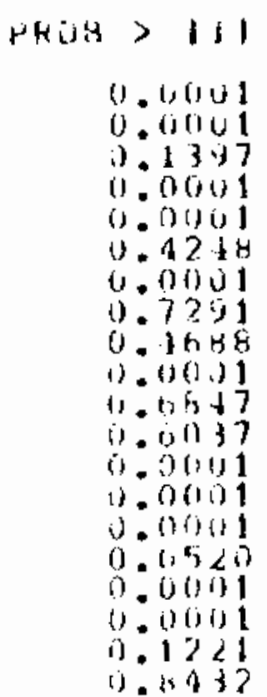




$$
\begin{aligned}
F & =\frac{(16,395,610,432-16,384,877,987) / 23}{16,384,877,987 /(2501-47)} \\
& =0.07
\end{aligned}
$$

The remaining test results are as follows:

Full sample, natural gas: $\quad F=0.17$

Restricted sample, electricity: $F=0.08$

Restricted sample, natural gas: $F=0.22$

The critical value $F_{c}$ at a $95 \%$ confidence level is no less than 1.50 for all of these tests. Therefore, the null nypothesis is accepted in all cases. 


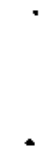




\section{REFERENCES}

ASHRAE. 1977. Handbook and Product Directory, Fundamenta] s. New York.

Departments of the Air Force, the Army, and the Navy. 1978. Facility Design and P Tanning: Engineering weather Data. AFM 88-29, TM 5-785, NAVFAC P-89.

Dubin, J.A., and D.L. McFadden. 1983. A Heating and Cooling Load Model for Single-Family Detached Dwellings in Energy Survey Data. Social Science Working Paper 469. Division of the Humanities and Social Sciences, California Institute of Technology, Pasadena, California.

Latta, R.B. 1983. Residential Energy Consumption Survey: Regression Analysis of Energy Consumption by End Use. DOE/E IA-0431. U.S. Department of Energy, Energy Information Administration, Washington, $0 . C$.

Office of Technology Assessment (OTA). 1979. Residential Energy Conservation, Vol. 1. OTA-E-92. U.S. Congress, Washington, D.C.

Pacific Northwest Residential Energy Consumption Survey. 1983. BPA 1544. U.S. Department of Energy, Bonnevilfe Power Administration, Portland, OR.

Rao, P., and R.L. Miller. 1971. Applied Econometrics. Wadsworth Publishing Company, Inc., Belmont, California. 
. 
APPENDIX A

CONSTRUCTION OF DEGREE DAYS ESTIMATES

FOR THE 1983 PACIFIC NORTHWEST

RESIDENTIAL ENERGY CONSUMPTION SURVEY

(PNWRES-83) 


\section{SUMMARY}

The 1983 Pacific Northwest Residential Energy Consumption Survey (PNWRES-83), sponsored by the Bonneville Power Administration, was conducted in the summer of 1983. Data on housing and appliance characteristics were collected from households in the Pacific Northwest region. Billing data from each consenting household's utility as well as demographic, economic and attitudinal information were also collected. Pacific Northwest Laboratory contracted with the Bonneville Power Administration (BPA) to construct indicators of climatic conditions (heating and cooling degree days) for the respondents in PAWRES who signed billing waivers. These indicators were constructed by assigning survey respondents to both:

- National Oceanic and Atmospheric Administration (NOAA) climatic divisions; and

0 weather stations located in the proximity of their residence.

This document presents a description of the procedures used to construct these data sets. 



\subsection{INTRODUCTION}

The Pacific Northwest Residential Energy Consumption Survey was conducted in the summer of 1983 to collect data on the residential energy sector. PNWRES has been an on-going data collection effort at BPA and was first administered in 1979. The survey data have been of substantial importance to BPA, the Northwest Power Planning Council, and the region's utilities in supporting load forecasting, conservation assessment, evaluation, and program planning.

The PNWRES surveys contain information on the physical characteristics of the residence (including square footage, presence of appliances, etc.) and attitudinal, economic, and demographic descriptions of the occupants of the residence. Billing histories for electricity and natural gas consumption are also provided.

However, since weather significantly affects energy consumption in the residential sector, indicators of the climatic conditions which prevailed over the period for which energy consumption data are provided are quite useful. A common indicator of climatic conditions is degree days. Heating and cooling degree days were constructed for the 1979 PNWRES survey--BPA thought it desirable to provide comparable metrics for the 1983 survey.

This appendix describes how the degree day estimates were constructed.

In the 1979 dataset, degree day estimates were provided for a temperature bas of $65^{\circ} \mathrm{F}$. The geographic resolution of the temperature data was National Oceanic and Atmospheric Administration climatic divisions (Figures A.1-A.4).

The choice of a proper base for construction of degree day estimates is, in part, dependent on the characteristics of the particular site examined. In constructing the degree day estimates for the 1983 dataset, therfore, we choose to provide several bases for degree days. Heating degree day bases included $55^{\circ} \mathrm{F}, 60^{\circ} \mathrm{F}, 65^{\circ} \mathrm{F}$, and $70^{\circ} \mathrm{F}$, while cooling degree bases were $65^{\circ}$ $\mathrm{F}, 70^{\circ} \mathrm{F}, 75^{\circ} \mathrm{F}$, and $80^{\circ} \mathrm{F}$. Because NOAA climatic divisions represent aggregations of reporting weather stations, degree day estimates were constructed at two levels of geographic aggregation: 1) NOAA climatic divisions, and 2) station level. 
Consistency with the 1979 dataset has been maintained by providing estimates for climatic divisions at the $65^{\circ} \mathrm{F}$ base.

\section{GEOGRAPHIC ASSIGNMENT}

In order to construct the climatic indicators, each PENWRES respondent had to be assigned to a particular climatic division and weather station. In both cases, the finest resolution that was practical for determining the location of a residence was the zipcode of the respondent.

The first step in constructing the indicators was to assign each unique zipcode to a specific NOAA climatic division. This was done by manually cross-referencing the city name of the zipcode with a map of NOAA Climatic divisions (see Figures A.1-A.4). Because the original data set provided to PNL had a number of zipcodes missing, a revised dataset was supplied in January of 1985.

Subsequent to assigning the zipcodes to NOAA climatic divisions, each zipcode was then assigned to a specific weather station by a PNL meteorologist using euclidean distance and elevation measures. Each assignment was reviewed for appropriateness and consistency by a Senior Research Scientist. (a)

Many of the weather stations have a significant number of missing data values. In instances where the primary station had one or more periods of missing data, the professional judgment of the PNL meteorologist was applied to reassign the zipcode to a secondary station for those periods.

The final geographic assignment step was to merge the datafile containing billing periods (or dates on which the consumption data were recorded) with the files containing the assignment of zipcodes to climatic divisions and weather stations. This step resulted in the following four files:

(a) The assignment of station numbers involved the concatenation of a unique NOAA station number and the assigned climatological division. Station identification numbers provided by NOAA on the temperature data tape include the climate identification number. The assignment, therefore, served as a check that the proper climate division assignment had been made. 
- for each observation with reported electricity consumption, the electricity billing dates and weather station assignment,

- for each observation with reported electricity consumption, the electricity billing dates and climatic division assignment,

- for each observation with reported natural gas consumption, the electricity billing dates and weather station assignment, and

- for each observation with reported natural gas consumption, the electricity billing dates and climatic division assignment.

The next step was to create the degree-day estimates.

\section{CONSTRUCTION OF DEGREE DAY ESTIMATES}

An average temperature was computed for each respondent for each billing period, according to the following formula:

AVG. TEMP $=($ MAX $T+$ MIN T $) / 2$

where MAX $T$ and MIN $T$ are the maximum and minimum temperatures recorded for each day during the billing period. Heating degree days (HDD) were computed as the maximum of (BASE - AVG. TEMP, 0), while cooling degree days (CDD) were computed as the maximum of (AVG. TEMP - BASE, 0). Finally, heating and cooling degree days for each billing period were computed as the sum of the HDDs and CDDs, respectively, for each day in the billing period; i.e.,

$$
\text { BILLING PERIOD DD = SUM (DAILY DD) }
$$

The computations resulted in the four data files describe above.

In the files relating to electricity consumption, there were 43 cases with unrecoverable problems. These cases were eliminated. In addition, if a faulty or inconsistent date was recorded in the billing data file, the date was suppressed by creating a single billing period from the two consecutive periods containing the faulty date.

\section{A. 5}




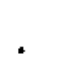




\section{ACKNOWLEDGMENTS}

Several people made significant contributions to this report. Guy McWethy performed most of the massive amount of data processing required by this project. He was assisted by Ken Burke. Mike King provided valuable comments and suggestions relating to the methodology.

Phillip Windell and Mike Warwick of BPA provided heipful comments on earlier drafts; these significantly improved the quality and accuracy of this report. 


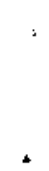




\section{DISTRIBUTION}

No. of

Copies

OFF SITE

5

Phillip Windell

BPA/KES

P.0. Box 362I

Portland, OR 97208

Mark Miller

BPA/KES

P.0. Box 3621

Portiand, OR 97208

Mike Warwick

BPA/KES

P.0. Box 3621

Portland, OR 97208

Chuck Foreman

$B P A$ - Division of Power Forecasting

2nd Floor, S.E.

847. N.E. 19th St.

Portland, OR 97208

Terry Morlan

Pacific Northwest Regional

Power Council

700 S.W. Taylor

Portland, OR 97205

Ken Corum

Pacific Northwest Regiona?

Power Council

700 S.W. Taylor

Portland, OR 97205

Fred Abel

U.S. Dept. of Energy

Office of Building Energy

Research and Buildings

Forrestal Building

1000 Independence Ave., 5.W.

Washington, DC 20585
No. of

Copies

OFFSITE

Chuck Schneider

BPA/PFN

P.0. Box 3621

Portland, OR 97208

Rich Gillman

$B P A / P F N$

P.O. Box 3621

Portland, $O R \quad 97208$

John McConnaughey

BPA /PFN

P.0. Box 3621

Portland, OR 97208

Tom Foley

Pacific Northwest Regional

Power Council

700 S.W. Taylor

Portland, OR 97205

Barry McNutt

Office of Policy, Safety and Environment

U.S. Dept. of Energy

Forrestal Building 1000 Independence Ave., S.W. Washington, DC 20585

Dianne Pirke

Office of Policy, Safety and Environment

U.S. Dept. of Energy

Forrestal Building

1000 Independence Ave., S.W. Washington, DC 20585 


\section{DISTRIBUTION}

No. of

Copies

OFFSITE

Eric Hirst

Oakridge National Laboratory

Box $X$

Oakridge, TN 37831

Dan Hamblin

Oakridge National Laboratory

Box $x$

Oakridge, TN 37831

Kathleen Hudson

Cambridge Systematics

2855 Telegraph Ave.

Suite 305

Berkeley, CA 94705

Mark Friedrichs

Building Services Division

U.S. Dept. of Energy

Forrestal Building

1000 Independence Ave., S.W.

Washington, DC 20585

30 DOE Technical Information Center

DOE Richland Operations office
No. of

Copies

ONSITE

50 Pacific Northwest Laboratory

R. C. Adams

W. B. Ashton

J. W. Callaway

R. F. Darwin

J. G. DeSteese (5)

J. E. Eng T in

P. L. Hendrickson

G. M. Holter

J. W. Johnston

M. S. KIan

A. D. Lee

A. J. Lyke

R. J. Moe

L. G. Mckethy

R. J. Nesse

R. G. Rivera

R. M. Scheer

T. J. Secrest

J. J. Tawil (20)

R. C. Tepel

Publishing Coordination (2)

Technical Information (5)

D. R. Segna 